\title{
ETHICAL COMMITMENTS AND FINANCIAL PERFORMANCE: EVIDENCE FROM PUBLICLY LISTED COMPANIES IN MALAYSIA
}

\author{
Ahmad Firdhauz Zainul Abidin, Hafiza Aishah Hashim*, and \\ Akmalia Mohamad Ariff \\ School of Maritime Business and Management, Universiti Malaysia Terengganu, \\ Terengganu, Malaysia \\ *Corresponding author: hafizaaishah@umt.edu.my
}

Published online: 29 December 2017

To cite this article: Abidin, A.F.Z., Hashim, H.A., and Ariff, A.M. (2017). Ethical commitments and financial performance: Evidence from publicly listed companies in Malaysia. Asian Academy of Management Journal, 22(2), 53-95. https://doi.org/10.21315/ aamj2017.22.2.3

To link to this article: https://doi.org/10.21315/aamj2017.22.2.3

\begin{abstract}
This study explores the role of business ethics towards corporate wealth creation and sustainable performance. In the context of Malaysia, the importance of committing to following the highest ethical standards is evidenced by the recommendations and guidelines imposed through the Malaysian Code of Corporate Governance (MCCG) 2012. The perspective from stakeholder theory indicates that commitment towards ethics has multiple, positive impacts to companies. One of the positive impacts, which is a result of being able to gain trust and secure loyalty from their stakeholders, is better financial performance. This study posits that management commitment towards ethics is positively associated with financial performance. Content analysis is used to systematically code and evaluate data from 243 publicly listed firms on the Main Board of Bursa Malaysia in year 2014. The Ethics Commitment Assessments Index (ECAI), which contains 14 items, is used to score commitment towards ethics. Financial performance is represented by return on assets (ROA) and return on equity (ROE). The results show a positive relationship between commitment towards ethics and financial performance. The findings contribute to policy formulation by suggesting that commitment towards ethics should continue to be emphasised by regulators because it is considered by stakeholders in assessing the risk of companies in the capital market.
\end{abstract}

Keywords: business ethics, commitment to ethics, financial performance, MCCG 2012

(C) Asian Academy of Management and Penerbit Universiti Sains Malaysia, 2017. This work is licensed under the terms of the Creative Commons Attribution (CC BY) (http://creativecommons. org/licenses/by/4.0/). 


\section{INTRODUCTION}

Ethical conduct in business is an important criterion for a corporation to compete in today's complex markets. Cases of ethical misconduct, such as the highly cited cases of Enron and Parmalat, were followed by legislative responses such as those involving corporate governance. In the context of Malaysia, Krishnan (2011) highlights corporate financial scandals like those of Megan Media Bhd., Transmile Bhd., and Welli Multi. Nevertheless, subsequent to the new legislations, there are still cases of ethical misconduct being reported. Dilemmas on whether to pursue self-interest or company interest often leads to corporate misconduct. According to Schweitzer, Ordóñez, and Douma (2004), motivation to achieve individual interest can lead to unethical behaviour. As reported in The Star Online dated 17 January 2014, KPMG reports that bribery, fraud, and corruption in Malaysia have increased nearly $100 \%$ in the last three years. The KPMG report suggests that the desire for wealthy lifestyles acts as a motivation behind the unethical behaviours. Thus, in the light of the worsening ethical misconduct in Malaysia, the need to explore corporate ethical issues is important and timely from both the perspectives of policy formulation and corporate practices.

Commitment to ethics by a firm, can be described as a firm's agenda in increasing their stakeholder's interest and maintaining a social relationship between firms and stakeholders. Stakeholders are attracted to firms with high ethical commitment because such commitment reflects the firms' responsibilities in ensuring sustainable performance. For investors, sustainable performance results in greater return on their investment, both in short- and long-term perspectives. Thus, corporate obligations, roles, and responsibilities to commit to high ethical standards are in line with the efforts to protect the shareholders' interest and maximise their values. In the context of Malaysia, the Malaysian Code of Corporate Governance (MCCG) 2012 directly emphasises on the role of the corporate board of directors and management in promoting ethical corporate conduct. Any company is expected to have clear policies involving corporate ethical commitments, whereas the managers are expected to maintain high discipline to avoid involvement in unethical conduct in their business operations. Although the objective of a corporation is increasing profits and maximising shareholders' wealth, stakeholders' interest should also be considered because they also play important role in determining corporate performance.

The effect of corporate commitment towards ethical behaviours can be viewed from the perspective of stakeholder theory. Firms that emphasise ethical commitments, whether within their operations or beyond, often experienced increases in their corporate values. When firms perform good ethical conduct in their operations, 
they will receive loyalty from their stakeholders, such as suppliers and customers. When firms show their commitment towards ethics in activities beyond their operations, such as having ethical sensitivity towards the environment, the firms will gain trust from stakeholders. All of these will result in sustainable financial performance of the firms. Accordingly, shareholders will be more attracted to firms that have sustainable financial performance, thus resulting in an increase in the firm's values.

This study examines whether corporate commitments to ethics affects their financial performance. Corporate commitments to ethics are disclosed in corporate annual reports and derived using the Ethics Commitment Assessments Index (ECAI). Financial performance is measured using return on assets (ROA) and return on equity (ROE). A number of 243 companies publicly listed in the Main Board of Bursa Malaysia in 2014 are used as the sample. The results show positive association between commitment to ethics and financial performance, which supports stakeholder theory. Findings indicate that firms that show their commitment toward ethics receive better return from stakeholders. Our findings are in support of the emphasis towards ethical corporate conduct by the Malaysian government, especially through the MCCG 2012. More specifically, the findings indicate that commitment towards ethical conduct is an aspect that should be practiced by companies, and made known to the stakeholders.

Our study is among the first to adopt an ethical disclosure index that incorporates the recommendations in MCCG 2012 in an empirical analysis examining the benefit of corporate commitment towards ethical conduct. By doing that, we incorporate the perspective of the Malaysian regulators in the development of the index and at the same time highlight the aspect of MCCG 2012. This approach has not received considerable attention in prior studies (i.e., recommendations towards ethical corporate conduct). Also, our study highlights the importance of corporate ethical conduct from the perspective of a developing country (i.e., Malaysia). In doing so, we add another perspective concerning mechanisms to curb unethical corporate conduct, aside from legislative framework that are often shown to be ineffective in the developing countries due to the lack of efficacy in their enforcement mechanisms. Corporate commitment towards ethical conduct is expected to be effective in detecting and preventing corporate misconduct and unethical behaviours in Malaysia, unlike the legislative framework that is treated to be just another hurdle to overcome by the perpetrators. 


\section{LITERATURE REVIEW}

\section{Stakeholder Theory}

The benefit of putting commitment on ethics in corporations can be explained by stakeholder theory. This study is related to the stakeholder theory by focusing on a firm's commitment towards ethics that can provide financial benefits towards firms. In theory, firms that well-managed their stakeholders' interest, reducing cost at the same time, help the firms' financial positions (Karim, Suh, \& Tang, 2016).

Stakeholder theory indicates that firms that fulfil a stakeholder's interest by promoting ethical conduct and being sensitive towards the environment tend to receive trust and loyalty from the stakeholders (Harrison \& Wicks, 2013). A formal definition of stakeholder theory is a model of corporate social responsibility that holds that business managers have ethical responsibilities to a range of stakeholders that goes beyond a narrow view that the primary or only responsibility of managers is to stockholders (Hartman, DesJardins, \& MacDonald, 2014). Firms that treat stakeholders well create values because the firms are considered to perform better (Harrison \& Wicks, 2013).

Mill (1961) proposed the idea that stakeholder happiness is also considered as a level toward stakeholder satisfaction when engaging with firms. According to Bosse, Phillips, and Harrison (2009), and Harrison, Bosse, and Phillips (2010) as cited in Harrison and Wicks (2013), there are additional requirements to create stakeholder values that are more than just meeting the satisfaction level of a stakeholder. Harrison and Wicks (2013), in constructing examples of performance measures from multiple stakeholder perspectives, include employees, customers, shareholders, suppliers, and the community. All these perspectives are measure based on each interest for the group. For example, a customer will be more happy and satisfied if firms produce high quality products and good services.

According to Phillips, Freeman, and Wicks (2014), some people misinterpret stakeholder theory to be tools for managers to take advantage for self-interest through benefits for some group of stakeholders against other stakeholder interests. Another critical view of stakeholder theory perspectives is that firms that tend to benefit stakeholders are considered to be opportunist because of taking advantage of the stakeholder. As in the definition of stakeholder, this consists of a group that affects or can affect managerial decisions and actions which include shareholder. Phillips et al. (2014) also stated that stakeholder theory stresses firms that intend to provide equal treatment for all groups of stakeholders. 


\section{Financial Performance}

Financial performance can be defined as the financial position for firms in their industries. According to Choi and Jung (2008), financial performance reflects a measurement from historical financial positions of companies. Firm performance is a term applied to an organisation's conduct and activities over a period, with reference to cost efficiency and accountability. It is also used to determine any success or loss for firms. Financial performance is the monetary term for measuring firms' operations and policies, and to assess financial conditions, income statements, and the balance sheets of companies (Adam, 2014). Firm performance can also reflect a firm's values (Rouf, 2011). The effectiveness and efficiencies of a firm's operations can be measured by financial performance (Neely, 2005). Firm performance is used to determine the success or loss for firms. According to Meigs (1978), analysis of a firm's financial performance is the process of selecting, relating, and evaluating the firm's operations, management, and decisions in monetary forms. Most corporate organisations measure their performance by analysing the sales-to-assets ratios, ROE, and ROA. For example, the study by Kabajeh, Al-Nu'aimat, and Dahmash (2012) utilised firms' financial performance ratios, which are ROA and ROE in their study. Bhunia, Mukhuti, and Roy (2011) used firm liquidity, solvency, profitability, and stability in the pharmaceutical sector to measure the weaknesses and strength of financial positions among public listed companies in India. They used the liquidity test, solvency, and profitability and accounting ratios in determining the financial performance.

\section{Commitment to Ethics}

Commitment to ethics has many definitions. Kanter (1968, as cited in Dixit and Bhati, 2012, p. 34) defines commitment as "the willingness of social actors to give their energy and loyalty to social systems, the attachment of personality systems to social relations, which are seen as self-expressive." It is the basic concept and fundamental principles of human conduct and belief. Salancik (1977) states that commitment can be defined as a bind between individual and actions. It is a belief from the individual perspective to get involved in organisations, and that the involvement will strengthen the bonds between individuals and organisations. Simply put, commitment is a promise to do something that is believed will transform the promise into reality. Meanwhile, ethics can be defined as a judgement and rules that are based on the basis of morality, which can be distinguished between right or wrong (Ferrell, Fraedrich, \& Ferrell, 2011). Therefore, commitment to ethics can be defined as a willingness, based on moral principle, belief, and actions, to conduct something good and promote in others in order to maintain the relationship within organisations. According to Verschoor (1998), commitment to ethics is an 
organisation's willingness to conduct operations as what have been written in its codes of ethical conduct. Meanwhile, commitment to ethics as an organisational commitment, which occurred in individuals, can promote increased organisation's performance (Wells, 2013; Zohdi, Maghool, Ramezani, \& Hosseini, 2013). Other studies implied that commitment to ethics involves corporate responsibilities towards ethical business conduct (Pae \& Choi, 2011). Pae and Choi (2011) added in their studies that high ethical standard practices in corporations reflect higher corporate valuation.

Commitment to ethics also describes how firm operations are committed within a framework of shareholder values, stakeholder interests, and social issues (Keim, 2001). Keim (2001) added that firms that have a commitment towards ethical values by investing in social issues are seen to have made a transactional investment. Furthermore, firms can be considered as having ethical conduct when the management is committed to promote the ethical codes and values towards employees in organisations (Valentine \& Barnett, 2003). Additionally, firms' commitments to ethics must be implemented at the management levels to create awareness among the stakeholders (i.e., employees, suppliers, customers, and society) towards organisation code of ethics and organisation policies. Thus, it is management commitment to promote the organisation's ethical values (Callaghan, 2012).

\section{Relationship between Commitment to Ethics and Financial Performance}

There are several studies focusing on business ethics in terms of corporate social performance (CSP) or commitment to ethics. Most studies focusing on the relationship between CSP and financial performance (Waddock \& Graves, 1997; Fu, Wang, \& Jia, 2012; Wang \& Berens, 2015; Fischer \& Sawczyn, 2013). Waddock and Graves (1997) focused on two types of CSP directions - which are slack resource, a resource that provide firms investing towards social relations; and good management, where good management practice improves stakeholders relationships with the company - which results better performance. Waddock and Graves (1997) have found a positive relationship between CSP and financial performance for all companies in the S\&P 500. The researchers concluded that firms with strong financial performance are able to invest in CSP by utilising slack resources, and by doing so, reflects the firm's positive image towards stakeholders who are then provided better financial returns.

The relationship between CSP and financial performance in China (Fu et al., 2012, p. 35) used ROE as accounting-based measures and Tobin's Q as market-based measures. The researchers argue that companies with high activities of corporate 
social responsibility (CSR) need to utilise more resources, thus affecting its current financial performance (ROE). Moreover, Fu et al. (2012) found negative relations between CSP and corporate financial performance (Tobin's Q) among companies in China. The researchers concluded that firms in China should emphasise on CSR, contributes towards society, employee, and natural environment, and by doing so improves their market values and financial positions.

Jauch, Glueck, and Osborn (1978) examined the relationship between commitment and performance. The study conducted by selecting samples among academicians to determine whether productivity of research has relationship with professional commitment. They found that those professionals with commitment have a positive relationship within research productivity. The greater the professional commitment, the greater the research productivity. This finding concludes that when individuals have high commitment, in their profession, productivity also increased. Similar to firms, manager commitment will drive the management towards ethical and improved performance.

According to Berman, Wicks, Kotha, and Jones (1999), in the intrinsic stakeholder commitment model, normative commitment in firms, based on morals, tends to treat stakeholders in a positive way, and based on financial returns, firms consider setting strategy based on financial performance. Generally, the relationship between management and stakeholder were based on an intrinsic stakeholder commitment model, which is more committed towards morality rather than maximising profits. Thus, this intrinsic model has significant affect towards the managerial decision to act ethically and morality as their values.

Watson (2010) discussed leader ethics and organisational commitment. Organisational commitment is defined as "a strong belief in and acceptance of the organization's goals and values, a willingness to exert considerable effort on behalf of the organization, and a definite desire to maintain organizational membership" (Mowday, Porter, \& Steers, 1979, p. 604 as cited in Watson, 2010). Commitment also can be constructed into three forms: (1) continuance commitment, evaluation tools towards members, (2) affective commitment, emotional-bond within organisation, and (3) normative commitment, which is perceived moral obligations (Meyer \& Allen, 1991, as cited in Watson, 2010). The study concluded that affective and normative commitment has a relationship with employees' perception of leaders' values. Thus, firms that can show its commitment towards ethical values, and encourage their employees by having clearly rules, and protecting employee interests, the manager can be seen as being an ethical person, thereby gaining commitment from employees to improve performance. 
Previous studies have looked into the relationship between commitment to ethics and financial performance. Verschoor (1998) found a positive relationship between firms' commitment to ethics and financial performance among the 500 largest companies in the US. Verschoor (1998) added that a company committed towards ethical behaviour inside corporate reports meet better financial performance. Meanwhile, Choi and Jung (2008) using a survey method based on the Ethical Commitment Index (ECI), found no relationship between commitment to ethics and financial performance among South Korean companies. These studies were researched further by Pae and Choi (2011) by focusing on corporate governance and business ethics. They found a positive relationship between corporate governance and business ethics with a firm's value among Korean public listed firms. According to Chandler (2015), firms that have a high commitment towards promoting ethical values and utilising the resources towards ethical practice will have a better reputation with stakeholders. Furthermore, stakeholders are sensitive towards a firm's activities, thus affecting financial performance.

\section{Hypotheses Development}

The relationship between commitment towards ethics and corporate financial performance has been examined from the perspective of cost of capital, market values, and corporate governance (CG) structure. For example, studies show that firms with comprehensive CG are valued highly in the stock market, and leads to better financial positions because investors are more likely to invest in firms that provide low risk and protect the investment (Pae \& Choi, 2011). More related to this study are those that have examined corporate commitment to ethics. Studies such as Van der Merwe, Pitt, and Berthon (2003), Verschoor (1998), and Vogel (1991) find a positive relationship between corporate commitment to ethics and financial performance (or corporate value). Thus, based on the evidence from the prior studies, Hypothesis 1 is constructed as follows:

H1: Management commitment towards ethics is positively associated with financial performance.

\section{METHODOLOGY}

\section{Sample Selection}

The sample firms in this study are publicly listed firms on the Main Board of Bursa Malaysia from the year 2014. A total of 260 firms are randomly selected from the total of 820 firms listed in 2014. The number in the sample were selected based 
on the Krejcie Morgan procedure in order to minimise error and achieve a 95\% confidence level (Krejcie \& Morgan, 1970). From the 260 companies, only 243 firms are in the final sample used for analysis because 17 firms are excluded due to missing data.

\section{Regression Model}

To test the hypothesis, multiple regression analysis is employed. Multiple regression analysis, as defined by Higgins (2005), is a tool to examine the relation between multiple independent variables and a dependent variable. It is also used to predict value of the dependent variable by using several independent variables. The regression models to test $\mathrm{H} 1$ are as follows:

For the first model where financial performance is proxied by ROA:

$$
\begin{aligned}
& R O A=\beta_{0}+\beta_{1} C O M M T+\beta_{2} F I R M_{-} S Z+\beta_{3} F I N_{-} L V G+\beta_{4} M K T+C A P+ \\
& \sum_{k=1}^{I I} \beta_{5+k} I N D+\varepsilon
\end{aligned}
$$

For the second model where financial performance is proxied by ROE:

$$
\begin{aligned}
& R O E=\beta_{0}+\beta_{1} C O M M T+\beta_{2} F I R M_{-} S Z+\beta_{3} F I N_{-} L V G+\beta_{4} M K T T_{-} C A P+ \\
& \sum_{k=1}^{I I} \beta_{5+k} I N D+\varepsilon
\end{aligned}
$$

where,

$R O A=$ financial performance measured by ROA

$R O E=$ financial performance measured by ROE

$C O M M T=$ management commitment

FIRM SZ = firm's size

FIN_ $\overline{L V} G=$ firm's financial leverage

$M K \bar{T} \_C A P=$ firm's market capitalisation

$I N D=$ industries

The models were expected to show that firms with a higher commitment towards ethics (COMMT) have a positive association with financial performance ROA (ROE) and proving hypothesis of this study. The model includes several control variables that are selected based on the commonly used measures in prior studies (e.g., Yu \& Choi, 2014; Wang \& Berens, 2015; Waddock \& Graves, 1997). They are: 
- Firm size (FIRM_SZ), which can be measured as firm's total assets, where

$$
\text { Firm's size }=\text { Total assets }
$$

- Financial leverage (FIN_LVG), otherwise known as debt ratio, measured by a firm's total liabilities divided by total assets

$$
\text { Financial leverage }=\frac{\text { Total liabilities }}{\text { Total assets }}
$$

- Market capitalisation (MKT_CAP), measured by multiplying a firm's shares outstanding by stock price per share. All these ratios were collected from Osiris database. Lastly, industries were measured by using Bursa Malaysia industries listings.

$$
\text { Market capitalisation }=\text { Oustanding shares } \times \text { Shares value }
$$

Moreover, firm size (FIRM_SZ), which is associated with strong financial performance (Pae \& Choi, 2011), contributed towards resource to commit to better ethical conduct. Financial leverage (FIN_LVG) is measured by using total liabilities divided by total assets (TL/TA) or debt-to-asset ratio. Financial leverage provides better capital structures but at the same time increases risk, where management need to reduce risk by meets creditors expectations and committed towards ethical conduct (Choi \& Jung, 2008). Market capitalisation (MKT_CAP) is also considered in the model, where it is associated with a firm's size (Pae \& Choi, 2011), which also reflects financial positions. Lastly, industry (IND) variable is also included in the model, which is the variety of industry reflects different commitment to ethics disclosure and financial performance. This is based on the findings of Fischer and Sawczyn (2013), who stated that companies in different industries have different ethical behaviour.

In measuring financial performance, variety of measures were used to rank a firm's performance. Basically, ratios such as ROA, ROE, profitability ratios, debtto-equity ratios, and market values are common measures of performance. For example, Kabajeh et al. (2012) used ROA, ROE, and return on investment (ROI) in examining the ratios relationship with share values of Jordanian insurance public companies. Boaventura, Silva, and Bandeira-de-Mello (2012) used ROA, ROE, return on sales (ROS), sales growth, market share, risk of the firm, return on capital employed (ROCE), and earnings per share (EPS) in order to indicate corporate financial performance. This study employs ROA and ROE as measures of financial performance. ROA is the most favourable proxies in measuring financial performance. ROA was chosen because it represents a firm's profitability (Fischer 
\& Sawczyn, 2013) and firms controlling their total assets to gain advantages that can return a profit (Hull \& Rothenberg, 2008). Firms' activities were related to the CSR that impacts towards ROA (Wang, Choi, \& Li, 2008). ROE is also considered to be the second proxies of financial performance. ROE were calculated using net income divided by total equity; it is also favourable among previous studies (Waddock \& Graves, 1997; Pae \& Choi, 2011; Fu et al., 2012; Saedi, Sofian, Saeidi, Saeidi, \& Saaeidi, 2015). According to Johnson and Greening (1999, as cited in Zabri, Ahmad, \& Wah, 2016), ROE is proven in measuring performance for both firm's stakeholder and shareholders. ROA and ROE were calculated using the following formulae:

$$
\begin{aligned}
& \text { ROA }=\frac{\text { Net income }}{\text { Total average assets }} \\
& \text { ROE }=\frac{\text { Net income }}{\text { Total equity }}
\end{aligned}
$$

The data for the ratios are derived from the annual reports and Osiris database.

\section{Measuring Commitment to Ethics}

The test variable is COMMT, which represents commitment to ethics. In measuring commitments to ethics, board statements from the annual reports of the publicly listed companies are examined. This approach is similar to prior studies on corporate commitment to ethics. More specifically, this study follows the studies on US firms conducted by Verschoor (1998) and Korean firms conducted by Pae and Choi (2011). To score the management commitments towards ethics, this study develops an ECAI index. In developing the index, the management commitment assessment items in Pae and Choi (2011) are adopted. The original index containing 11 items, constructed by Pae and Choi (2011), is revised by considering the Malaysian corporate practices. More specifically, recommendations from the MCCG 2012 in relation to the management commitment towards ethics in organisations are examined. Three items from the MCCG were added into the index in this study. The ECAI consists of 14 items, as presented in Table 1.

In Table 1, items 1 to 11 are adapted from Pae and Choi (2011), and items 12, 13, and 14 are added based on the MCCG 2012 and firm's practices. Item 12 was added based on the recommendations from the MCCG 2012, which stated: "The code of conduct should include appropriate communication and feedback channels which facilitate whistleblowing." 
Table 1

The ECAI index

\begin{tabular}{ll}
\hline & Items \\
\hline 1. & Top managers of this company regularly emphasise the importance of business ethics. \\
2. & Ethical behaviour based on a formal business philosophy is the norm of this company. \\
3. This company has a disciplinary system through which unethical behaviour is strictly \\
punished. \\
4. This company has a code of ethics. \\
5. In this company, employees can report unethical conduct through an anonymous channel. \\
6. In this company, ethics education, training, or workshops are in place to enhance business \\
7. This of employees. \\
8. This company regularly puts a significant portion of its profits towards philanthropy. \\
9. In this company, employees can get help regarding business ethics through an ethics hotline \\
10. This company has an ethics committee. \\
11. This company has an ethics evaluation system measured by an independent party from \\
12. The board of this company have established the Whistleblowing Policies. \\
13. The board of this company committed to achieve business sustainability. \\
14. The board of this company committed to conduct business in accordance with the highest \\
ethical standards.
\end{tabular}

Additionally, the statement on establishment of a whistleblowing policy also were provided from several firms that stated:

The Group implemented the Whistleblowing Policies and Procedures ("Whistleblowing Policy") to address whistleblowing matters; and the Whistleblowing Policy describes the Group's Speak-Up Policy, avenues for filing a concern and handling of whistleblowing incidents by the employees and external party or any insurance intermediary (Allianz Malaysia Berhad, 2014, p. 74).

Item 13 was added based on board commitment in promoting and achieving financial, social, and environmental sustainability for the firm:

The board should ensure that the company's strategies promote sustainability. 
The board should formalise the company's strategies on promoting sustainability. Attention should be given to environmental, social and governance (ESG) aspects of business which underpin sustainability (Securities Commission Malaysia, 2012, p. 12).

For example, CIMB Bank Malaysia and Cocoaland Holdings Berhad stated that:

As a good corporate citizen, CIMB has shifted its focus from giving back to the community to addressing the concerns of stakeholders regarding issues impacting the long-term sustainability of CIMB's business and customers (CIMB Group, 2014a, p. 157).

The Board recognises the need for the Company's strategy to include sustainability on the operations. A sustainability process would help the Company to set goals, measure its performance and manage changes in its business (Cocoaland Holdings Berhad, 2014, p. 16).

Item 14 was added based on the board commitment towards highest ethical standards in conducting business: "The board should formalise ethical standards through a code of conduct and ensure its compliance" (Securities Commission Malaysia, 2012). An example of this statement can be found from British-American Tobacco (Malaysia) Berhad and Amway (Malaysia) Holdings Berhad:

The Company and its Board of Directors (Board) remain steadfast in its commitment in maintaining high standards of corporate governance. The Board firmly believes that the integrity and commitment of its Board and employees, supported by a comprehensive framework of policies guidelines and internal controls, will serve to strengthen the Company's sustainability, organisational effectiveness and drive a high-performance culture within the organisation [British-American Tobacco (M) Berhad, 2014].

The Board recognises the importance of enhancing shareholder value through building a sustainable business by implementing and maintaining high standards of corporate governance in managing the business affairs of the Company [Amway (M) Holdings Berhad, 2014, p. 25]. 
In measuring disclosure items, most previous studies used a scoring method, whether binary scoring (Haniffa \& Cooke, 2000; Mia \& Al-Mamun, 2009) or rating scoring that is based on quality of disclosure and sentence structure (Verschoor 1998; Pae \& Choi, 2011; Fu et al., 2012). Binary scoring $(0,1)$ system is favourable among previous studies related to the social disclosures (see Haniffa \& Hudaib, 2007; Wang \& Berens, 2015). This study uses binary scoring for each ECAI item. Each item is scored as one (1) if the item existed and zero (0) if not exist. The score is calculated in percentage; where each score of a company is divided by total scores.

$\frac{1}{n} \sum_{c} \times 100 \%$

Where $n$ is the number of total scores which is 14 , and $c$ is the scores for each company. The higher the ECAI score, the higher the management commitment towards ethics in the firms.

\section{RESULTS}

\section{ECAI Disclosure Statistics}

Table 2 displays the results of frequency analysis of 14 ECAI items for the 243 firms in the sample.

Table 2

Frequency analysis of ECAI items

\begin{tabular}{lllll}
\hline Item & \multicolumn{2}{l}{ Item not disclosed } & \multicolumn{2}{l}{ Item disclosed } \\
\cline { 2 - 5 } & Frequency & $\%$ & Frequency & $\%$ \\
\hline 1 & 122 & 50.2 & 121 & 49.8 \\
2 & 129 & 53.1 & 114 & 46.9 \\
3 & 221 & 90.9 & 22 & 9.1 \\
4 & 64 & 26.3 & 179 & 73.7 \\
5 & 197 & 81.1 & 46 & 18.9 \\
6 & 178 & 73.3 & 65 & 26.7 \\
7 & 46 & 18.9 & 197 & 81.1 \\
8 & 231 & 95.1 & 12 & 4.9 \\
9 & 226 & 93.0 & 17 & 7.0 \\
\hline
\end{tabular}


Table 2 (continued)

\begin{tabular}{lllll}
\hline Item & \multicolumn{2}{l}{ Item not disclosed } & \multicolumn{2}{l}{ Item disclosed } \\
\cline { 2 - 5 } & Frequency & $\%$ & Frequency & $\%$ \\
\hline 10 & 220 & 90.5 & 23 & 9.5 \\
11 & 237 & 97.5 & 6 & 2.5 \\
12 & 129 & 53.1 & 114 & 46.9 \\
13 & 59 & 24.3 & 184 & 75.7 \\
14 & 34 & 14.0 & 209 & 86.0 \\
\hline
\end{tabular}

Based on Table 2, 121 firms (49.8\%) disclosed item 1 where top managers or board emphasised the importance of business ethics. For example, the statement from Telekom Malaysia Berhad committed to promoting business ethics in their operations:

TM's firm commitment to enhancing and strengthening our corporate governance and business ethics, as well as inculcating ethical behaviour among the workforce and representatives of the Company. We have, in fact, two arms looking into ethics and integrity (Telekom Malaysia Berhad, 2014, p. 17).

Meanwhile, 114 firms (46.9\%) disclosed item 2 that suggested the firm's commitment by having philosophy towards ethical conduct. Basically, the philosophy is stated as part of the vision or mission of firms to show their commitment to ethics. For example, CIMB Bank Malaysia states five core values as the main philosophy in their operations:

(1) CUSTOMER-CENTRIC: We exist to serve our customers and we sell products and services that our customers understand and value; (2) HIGH PERFORMANCE: We work hard and we work strategically for customers, staff and other stakeholders; (3) ENABLING PEOPLE: We empower and align our people to innovate and deliver value in their workplace as well as for the community they serve; (4) STRENGTH IN DIVERSITY: We have respect for different cultures, we value varied perspectives and we recognise diversity as a source of strength; (5) INTEGRITY: We are honest, respectful and professional in everything we do because integrity is the founding value of CIMB Group (CIMB Group, 2014a, p. 2). 
For item 3, only 22 firms (9.1\%) have disciplinary action towards unethical behaviours among workers. For example, a statement from CIMB Bank Malaysia explained further actions towards unethical conduct among employees:

The Group ensures prompt investigations and disciplinary actions are taken against offending employees. Disciplinary actions taken can include dismissal of employment and filing of civil suit for the recovery of losses. Employees are trained to handle the personal information securely and with the utmost respect. Failure to do so may result in disciplinary action (CIMB Group, 2014b, p. 93).

Item 4 explains the actions from the board to establish a code of ethics or code of conduct in firms. A number of 179 firms (73.7\%) disclosed item 4. There were several types of sentence structures that show the firms have established a code of ethics towards board and employees. For example, Advanced Synergy Berhad established a code of conduct and ethics for both directors and employees: "The Company's Code of Conduct for Directors and employees continue to govern the standards of ethics and good conduct expected of Directors and employees" (Advanced Synergy Berhad, 2014, p. 13).

Meanwhile, other companies adopted a code of business ethics provided from Companies Commission of Malaysia, such as Aturmaju Resources Berhad: "The Directors shall be guided by the Code of Ethics for Directors issued by the Companies Commission of Malaysia. The Directors shall observe the Code of Ethics in performance of their duties" (Aturmaju Resources Berhad, 2014, p. 9).

Item 5 refers to the commitment from the board and management towards ethics by providing a reporting channel to report unethical cases related to the firm's business or wrongdoings among employees. Forty-six firms (18.9\%) disclosed this item. Sixty-five firms, or $26.7 \%$ of total sample, disclosed item 6 , where the board and management team facilitated training towards employees in improving their skills. These firms also show their commitment by regularly reminding their employees about the importance of business ethics by providing seminars and booklets for references. For example:

The group-wide programmes conducted during the year to embed the right ethical values and compliance with Maybank's Code of Ethics amongst all Maybank employees included the following: (1) Annual e-Learning Code of Ethics Declaration; (2) Training through induction for new employees; and (3) e-Capsule messages are screened through MyPortal to remind and ensure 
compliance to the Code of Ethics (Malayan Banking Berhad, 2014, p. 179).

Meanwhile, 197 firms, or $81.1 \%$ from 243 samples, disclosed item 7 that stated conducting philanthropic activities and CSR activities. This demonstrates that most firms are showing their commitment towards social and environmental ethical concerns. Certain firms only disclosed their philanthropic activities in general sentences:

The Group plays its role as a socially responsible corporate citizen in the community whenever the need arises. The Group is active and aware on community welfare by supporting needy social objectives in the communities in which its businesses operate and its employees live and work (Chuan Huat Resource Berhad, 2014, p. 110).

Other companies explained philanthropy in detail, such as utilising donations towards underprivileged children, schools, and engaging with various parties in utilising charitable giving. For example:

BHIC is committed to support and engage communities through its various business divisions. This forms a fundamental pillar in its CSR initiative to engage key stakeholders such as local communities, charitable organisations and Non-Governmental Organisations (NGOs). As part of our commitment towards community, BHIC group made contributions in cash and equipments to selected organisations including orphanages, an old folks home, and schools (Boustead Heavy Industries Corporations Berhad, 2014, p. 45).

Item 8 stated the commitment from the board or management to have an independent ethics department and officers. Only 12 firms disclosed this item. An example of disclosure is found in the following statement:

Employees and stakeholders who reasonably and in good faith believe that malpractices exist within the Company are able to report their concerns to the Audit Committee Chairman or the Independent Non-Executive Director (Daibochi Plastic and Packaging Industry Berhad, 2014, p. 12). 
It is believed that this is not possible or appropriate, then the concern should be reported to the Senior Independent NonExecutive Director of the Company [Harrisons Holdings (M) Berhad, 2014, p. 9].

Item 9 also has low disclosure among companies, of which only 17 firms, or $7.0 \%$, disclosed this item in their reports. Item 9 represents firms' commitment to ethics by providing an ethical hotline for their employees in gaining information of ethical issues or improving knowledge on ethical conduct. There were also only 23 firms that disclosed item 10 where the board established an ethics committee to promote ethical values and controlling risk. Some firms established separate ethics committee, for example:

The establishment of our Enterprise Ethics and Integrity Unit (EEIU) back in February 2013 is testament of TM's firm commitment to enhancing and strengthening our corporate governance and business ethics, as well as inculcating ethical behaviour among the workforce and representatives of the Company (Telekom Malaysia Berhad, 2014, p. 17).

Meanwhile, some firms facilitate the audit committee or risk management committee in reviewing ethical matters.

Audit committee/ethic Line Review of matters in relation to legal compliance, conflicts of interest, investigation and ethical conduct. Review of the Ethics Line Procedures to address allegations made by whistle blowers, to ensure proportionate and independent investigation are duly conducted and follow-up action is taken and brought to the attention of the AC (ASTRO Malaysia Holdings Berhad, 2014, p. 66).

Item 11 represents ethics evaluation from outside companies. Only six firms disclosed this item. For example: "The Board has established an independent internal audit function that reports directly to the Audit Committee. This internal auditor function is outsourced to Russell Bedford Malaysia Business Advisory Sdn. Bhd.” (Emas Kiara Industries Berhad, 2014, p. 13).

In terms of recommendations from MCCG 2012, items 12, 13, and 14 represent a firm's commitment to ethics by following guidance provided by MCCG 2012. There were 114 firms, or $46.9 \%$ from 243 firms, that disclosed item 12 whereby the board of the company established Whistleblowing Policies, reflecting the 
recommendation 1.3 in MCCG 2012: "The code of conduct should include appropriate communication and feedback channels which facilitate whistleblowing" (Securities Commission Malaysia, 2012).

For example, as being stated in Allianz Malaysia Berhad Annual Report, whistle blowing mechanisms were established as a part of company's policy in reporting unethical conduct, which provide details and procedures in reporting: "The Group implemented the Whistleblowing Policies and Procedures ('Whistleblowing Policy') to address whistleblowing matters; and the Whistleblowing Policy describes the Group's Speak-Up Policy, avenues for filing a concern and handling of whistleblowing" (Allianz Malaysia Berhad, 2014, p. 74).

Meanwhile, $75.7 \%$ from 243 firms disclosed item 13, which is the board of a company is committed to achieve sustainability that reflects firms in fulfilling recommendation 1.4 in MCCG 2012: "The board should formalise the company's strategies on promoting sustainability. Attention should be given to environmental, social and governance (ESG) aspects of business which underpin sustainability" (Securities Commission Malaysia, 2012).

In analysing item 13, each of the companies have their own definition of sustainability, a general statement that can be viewed under the board strategies in promoting sustainability, which is one of the recommendations from MCCG 2012. For example:

The Board recognises the need for the Company's strategy to include sustainability on the operations. A sustainability process would help the Company to set goals, measure its performance and manage changes in its business. The effort would continue to be monitored by the Board in helping to shape the Company's strategy and policy and ultimately to improve the overall performance (Asia Bioenergy Technologies Berhad, 2014, p. 10).

Additionally, sustainability also defines a firm's responsibility in giving back towards society in achieving long term business sustainability, for example: "As a good corporate citizen, CIMB has shifted its focus from giving back to the community to addressing the concerns of stakeholders regarding issues impacting the long-term sustainability of CIMB's business and customers" (CIMB Group, 2014a, p. 2).

The last item is item 14, which reflected the overall recommendation from the MCCG for each public listed firm to show and maintain their highest standard in 
conduct and business practice. Item 14 is the highest disclosure score where 209, or $86.0 \%$ from 243 firms, showed that the majority of firms from the samples attempted to fulfil recommendations from MCCG 2012 in maintaining highest standards in their operations. The sentence structures can be simply recognised under corporate governance section inside annual reports which reflect a firm's commitment towards highest standards of ethical conduct by complying MCCG 2012 recommendations. For example:

The Board of Asia Bioenergy Technologies Berhad (the "Company") recognises the importance of adopting high standards of corporate governance in the Company in order to safeguard stakeholders' interests as well as enhancing shareholders' value. The Directors consider corporate governance to be synonymous with four key concepts, namely transparency, accountability, integrity as well as corporate performance ... This corporate governance statement ("Statement") sets out how the Company has applied the 8 Principles of the Malaysian Code on Corporate Governance 2012 ("MCCG 2012") and observed the 26 Recommendations supporting the Principles during the financial year following the release of the MCCG 2012 by the Securities Commission of Malaysia in late March 2012 (Asia Bioenergy Technologies Berhad, 2014, p. 10).

A majority of firms used the sentences such as in the following examples:

The Board of Directors ("the Board") of Group and ("the Company") is committed/ promote/ recognised the important of business ethics (Euro Holdings Berhad, 2014, p. 17; Focus Point Holdings Berhad, 2014, p. 22).

To ensure that good corporate governance practices are applied/ ensure that the high standards of corporate governance are practised throughout the Company and its subsidiaries ("the Group") (Country Heights Holdings Berhad, 2014, p. 64; CN Asia Corporation Berhad, 2014, p. 13).

The Board fully supports the principles and recommendations of good corporate governance practices as promulgated by the Malaysian Code of Corporate Governance 2012 ("the Code") (Aturmaju Resources Berhad, 2014, p. 9; Asia Media Group Berhad, 2014, p. 37). 
These types of sentences reflect the boards' commitment towards achieving highest ethical conduct in business by supporting recommendations from MCCG 2012, and can be found in majority of firms annual reports.

To conclude, in terms of the disclosure of commitment to ethics, as represented by the ECAI score, majority of the firms explain in detail their commitment to ethics. The results suggest that most firms show their concern towards the importance of ethical conduct in their business because ethical conduct affects their sustainability in the future. Certain items are not disclosed in detail, such as item 4, 7, and $12-$ especially among small firms.

\section{Descriptive Statistics of Variables}

Table 3 provides descriptive statistics for continuous variables where both ROA and ROE were financial performance indicators measured in percentage. For COMMT, measurement of management commitment is the mean score. Firms' size (FIRM_SZ) is measured in Malaysian Ringgit (RM) from actual values of each firm's total assets. Financial leverage (FIN_LVG) was measured using debt ratio (total liabilities divided by total assets) in percentage. Lastly, market capitalisation (MKT_CAP) is measured from actual values of a firm's market capitalisation. From the table, the mean value for ROA is $4.137 \%$, minimum value is $-84.35 \%$, shows not all companies in the sample recorded profits. Maximum ROA value is $94.92 \%$, meanwhile the mean value for ROE is 8.398 . In fact, the abnormal values for maximum values of ROE were $232.52 \%$ and was the highest ROE overall from 243 samples. The numbers indicate that one of the firms utilise their shareholders investment efficiently. Minimum values for ROE is $-67.59 \%$, indicating one firm is managing their shareholder investment inefficiently. The mean value for COMMT is 0.385 with a standard deviation of 0.357 , minimum is 0.071 , and maximum is 0.929. For FIRM_SZ, the mean value is RM6,629,000,000, minimum value is RM6,981,000 and maximum value is RM640,299,956,000 which indicates one firm has large total assets and has a large source of funds can utilise for ethics and other social activities. For FIN_LVG, the mean value is $0.383 \%$, minimum is $0.005 \%$, and maximum is $1.861 \%$. The abnormal value for maximum value of FIN_LVG indicates one firm in the 243 sample has high liabilities and debt that exceed their assets. This shows the company faces unhealthy financial positions. The abnormal value for minimum value of FIN_LVG indicates that several firms in Malaysia have low liabilities than their total assets and have not depended on loans. These data suggest that those firms are able to manage their debt and assets. The extremely low leverage among Malaysian companies in 2014 is consistent with the fact that most Malaysian companies were in less riskier conditions and only few companies funded their assets by using debt in 2014 (Salim \& Yadav, 
2012). In line with that, Bank Negara Malaysia has reported that the leverage of Malaysian companies are maintained at low level after global financial crisis. The low leverage reflects the situation where each industry has different ways of funding their capital. Industries such as telecomunications, oil and gas, and infrastructure depends more on market-based financing due to larger and longer funding requirement (Bank Negara Malaysia, 2014). Lastly, the mean value for MKT_CAP is RM2,302,870,000, minimum is RM5,850,000 and maximum value is $\mathrm{RM} 85,455,505,000$.

Table 3

Descriptive statistics for continuous variables

\begin{tabular}{lllllll}
\hline $\begin{array}{l}\text { Continuous } \\
\text { variables }\end{array}$ & $\begin{array}{l}\text { ROA } \\
(\%)\end{array}$ & $\begin{array}{l}\text { ROE } \\
(\%)\end{array}$ & COMMT & $\begin{array}{l}\text { FIRM_SZ } \\
(\mathrm{RM})\end{array}$ & $\begin{array}{l}\text { FIN_LVG } \\
(\%)\end{array}$ & $\begin{array}{l}\text { MKT_CAP } \\
(\mathrm{RM})\end{array}$ \\
\hline $\mathrm{N}$ & 243 & 243 & 243 & 243 & 243 & 243 \\
Mean & 4.137 & 8.398 & 0.385 & $6.63 \times 10^{9}$ & 0.383 & $2.30 \times 10^{9}$ \\
Median & 4.000 & 7.780 & 0.357 & $3.58 \times 10^{8}$ & 0.364 & $1.61 \times 10^{8}$ \\
Std. deviation & 14.218 & 24.137 & 0.172 & $5.01 \times 10^{10}$ & 0.229 & $8.93 \times 10^{9}$ \\
Minimum & -84.350 & -67.590 & 0.071 & $6.98 \times 10^{6}$ & 0.005 & $5.85 \times 10^{6}$ \\
Maximum & 94.920 & 232.520 & 0.929 & $6.40 \times 10^{11}$ & 1.861 & $8.55 \times 10^{10}$ \\
\hline
\end{tabular}

Table 4 shows that firms in the industrial production industry (INDUS_PROD) are $27.6 \%$ of the total sample. The real estates investment trust industry (REITS) is only $2 \%$ from the total sample. The finance industry (FINANCE) contributes to $2.9 \%$ from 243 firms, while the consumer industry (CONSUMER) is $15.9 \%$. The construction industry (CONSTRUCTION) is $4.9 \%$ and the trade/service industry (TRADE_SERVICE) is $21.5 \%$. The technology industry (TECHNOLOGY) contributes $11.4 \%$ whereas the properties industry (PROPERTIES) contributes to $8.1 \%$ of the total sample. Lastly, (PLANTATION) industries consist of $4.5 \%$ of the total sample.

Table 4

Descriptive statistics for firm's industry

\begin{tabular}{lccc}
\hline & Frequency & Percentage from sample & $\begin{array}{c}\text { COMMT score } \\
(\%)\end{array}$ \\
\hline INDUS_PROD & 68 & 27.60 & 37.82 \\
REITS & 5 & 2.00 & 40.00 \\
FINANCE & 7 & 2.90 & 55.10 \\
CONSUMER & 39 & 15.90 & 36.08 \\
\hline
\end{tabular}


Table 4 (continued)

\begin{tabular}{lccc}
\hline & Frequency & Percentage from sample & $\begin{array}{c}\text { COMMT score } \\
(\%)\end{array}$ \\
\hline CONSTRUCTION & 12 & 4.90 & 38.69 \\
TRADE_SVS & 53 & 21.50 & 42.72 \\
TECHNOLOGY & 28 & 11.40 & 33.67 \\
PROPERTIES & 20 & 8.10 & 35.71 \\
PLANTATION & 11 & 4.50 & 36.36 \\
Total & 243 & 100 & \\
\hline
\end{tabular}

From the table, commitment to ethics (COMMT) scores for each industry are also presented. The calculation for each score is based on the average score for each item in ECAI and is divided by the number of firms for each industry.

$$
\frac{\sum_{i}^{n} a i}{(n \times 14)}
$$

where, $n$ is the number of firms in industry, $a$ is score for each firms in industry, and 14 is total score for ECAI items.

On average, each industry has scores between $30 \%$ and $40 \%$. The highest scores were $55.1 \%$ from finance industry and the lowest from technology industry $(33.67 \%)$.

\section{Pearson Correlation}

Table 5 provides correlation analysis, which is performed to test the correlations between variables in the model. From Table 5, COMMT are correlated with financial performance in terms of ROA, at the significance level of $1 \%(p<0.01)$. Meanwhile, COMMT, FIN_LVG, and MKT_CAP are correlated with ROE at the significance level of $1 \%(p<0.01)$. Overall, there is a weak correlation between COMMT and financial performance (ROA, ROE) with Pearson coefficient below 0.4. Except for the correlations between MKT_CAP and COMMT, and MKT CAP and FIRM_SZ, other independent variables show weak correlation with each other because the coefficient values are generally lower than 0.4 .

According to Pallant (2011), multicollinearity exists between independence variables if $(r>0.9)$. Because the highest value of correlation is 0.827 , which $(\mathrm{r}<0.9)$, there is no multicollinearity existing between independent variables in the sample. Ghasemi and Zahediasl (2012) also added that the assumptions of 
normality should be taken seriously for data smaller than $50,(\mathrm{~N}<50)$. If the data sample is larger than 50 , the violation of normality will not be a major problem for analysis. Hair Jr., Black, Babin, and Anderson (2014) also stated that with sample size smaller than 50 , the violations of normality will cause major problems towards results. Furthermore, the exceptions of assumption exist when the sample size is large enough (i.e., $\mathrm{N}=200$ or more). Based on Hair Jr. et al.'s (2014), this study neglects the assumptions of normality.

Table 5

Pearson correlation analysis

\begin{tabular}{|c|c|c|c|c|c|c|}
\hline $\mathrm{N}=243$ & ROA & ROE & COMMT & FIRM_SZ & FIN_LVG & MKT_CAP \\
\hline $\mathrm{ROA}$ & 1 & & & & & \\
\hline ROE & $0.827^{\text {*k }}$ & 1 & & & & \\
\hline COMMT & $0.220^{* *}$ & $0.284^{* * *}$ & 1 & & & \\
\hline FIRM_SZ & -0.015 & 0.034 & $0.227^{* *}$ & 1 & & \\
\hline FIN_LVG & -0.104 & $0.137^{*}$ & 0.047 & $-0.145^{*}$ & 1 & \\
\hline MKT_CAP & 0.119 & $0.211^{* * *}$ & $0.443^{* *}$ & $0.755^{* *}$ & -0.049 & 1 \\
\hline
\end{tabular}

\section{Multiple Regression Analysis}

The results of the multiple regression analysis, to test H1, are shown in Table 6 . From the table, adjusted $\mathrm{R}^{2}$ for first model is 0.052 , which means that the model can explain $5.2 \%$ of the variance of ROA. The F-value is significant at $5 \%$ level $(p<0.05)$. For the second model, the adjusted $\mathrm{R}^{2}$ is 0.127 , which means that $12.7 \%$ the variables in the model can predict ROE. The F-value is significant at $1 \%$ level $(p<0.01)$.

In the first model, where the dependent variable is ROA, commitment to ethics, represented by COMMT, is significant at $5 \%$ significance level $(p<0.05)$. The beta coefficients is 0.188 , indicating positive association between COMMT and ROA. This positive association indicates that most firms in the sample had better performance when providing commitment towards ethics. Meanwhile, FIRM_SZ and FIN_LVG have significant association with ROA, at the 5\% significance level $(p<0.05)$, with beta coefficients of -0.265 and -0.157 , respectively. MKT_CAP also shows significant association with ROA, at a significance level of $10 \%$ $(p<0.10)$. 
In the second model, where the dependent variable is ROE, COMMT has significant association with ROE at the $1 \%$ significance level $(p<0.01)$, with beta coefficients of 0.204. Meanwhile, FIRM_SZ has a negative association with ROE at the 5\% significance level $(p<0.05)$. MKT_CAP is also significantly associated with ROE at the $1 \%$ significance level $(p<0.01)$.

Table 6

Regression analysis for ROA and ROE models

\begin{tabular}{|c|c|c|c|c|c|c|}
\hline & \multicolumn{3}{|c|}{ Model 1} & \multicolumn{3}{|c|}{ Model 2} \\
\hline & $\begin{array}{l}\text { Beta }^{\mathrm{a}} \\
\text { Coefficients }\end{array}$ & $t$ & Sig. & $\begin{array}{l}\text { Beta }^{\mathrm{b}} \\
\text { Coefficients }\end{array}$ & $t$ & Sig. \\
\hline (Constant) & & -0.252 & 0.801 & & -2.637 & 0.009 \\
\hline COMMT & 0.188 & 2.609 & $0.010 * *$ & 0.204 & 2.950 & $0.004 *$ \\
\hline FIRM_SZ & -0.265 & -2.368 & $0.019 * *$ & -0.258 & -2.400 & $0.017 * *$ \\
\hline FIN_LVG & -0.157 & -2.389 & $0.018^{* *}$ & 0.088 & 1.392 & 0.165 \\
\hline MKT_CAP & 0.210 & 1.956 & $0.052 * * *$ & 0.293 & 2.842 & $0.005^{*}$ \\
\hline Industry & \multicolumn{3}{|l|}{ Included } & \multicolumn{3}{|l|}{ Included } \\
\hline Adjusted $\mathrm{R}^{2}$ & \multicolumn{3}{|l|}{0.052} & \multicolumn{3}{|l|}{0.127} \\
\hline F-value & \multicolumn{3}{|l|}{$2.106^{* *}$} & \multicolumn{3}{|l|}{$3.928^{*}$} \\
\hline \multicolumn{7}{|c|}{$\begin{array}{l}\text { aROA }=\beta 0+\beta 1 \mathrm{COMMT}+\beta 2 \mathrm{FIRM} \_\mathrm{SZ}+\beta 3 \mathrm{FIN} \_L V G+\beta 4 \mathrm{MKT} \_\mathrm{CAP}+\beta 5 \mathrm{INDUSTRY} 1 \ldots+ \\
\beta 11 \mathrm{INDUSTRY} 11\end{array}$} \\
\hline \multicolumn{7}{|c|}{$\begin{array}{l}\mathrm{bROE}=\beta 0+\beta 1 \mathrm{COMMT}+\beta 2 \mathrm{FIRM} \_\mathrm{SZ}+\beta 3 \mathrm{FIN} \_L V G+\beta 4 \mathrm{MKT} \_\mathrm{CAP}+\beta 5 \mathrm{INDUSTRY} 1 \ldots+ \\
\beta 11 \mathrm{INDUSTRY} 11\end{array}$} \\
\hline
\end{tabular}

Notes: $* * *$ significant at $10 \%$ significance level $(p<0.10), * *$ significant at $5 \%$ significance level $(p<0.05)$,

* significant at $1 \%$ significance level $(p<0.01)$

\section{Additional Analysis}

In order to ensure the robustness of this study, the original ECI index from Pae and Choi (2011) contained 11 items were used in same analysis using multiple regression method.

Table 7 shows that commitment to ethics proxies from original indexes, (COMMT ECI) created by Pae and Choi (2011) have positive association with ROA, with beta coefficients 0.198 at $1 \%$ significance level $(p<0.001)$. Meanwhile, FIRM_SZ and a firm's FIN_LVG have a negative association with ROA, with beta coefficients -0.265 and -0.162 , respectively at the $5 \%$ significant level $(p<0.005)$. For MKT CAP, there is a positive association with ROA, with a beta coefficient 0.200 at the $10 \%$ significant level $(p<0.10)$. 
For the second model, ROE and COMMT_ECI also have positive association with ROE, with a beta coefficient 0.212 at the 5\% significant level $(p<0.05)$. FIRM_SZ has a negative association with ROE, with beta coefficient -0.259 at the $5 \%$ significance level $(p<0.05)$. FIN_LVG has positive asscociation with ROE, with beta coefficient 0.083 , but is not significant. Lastly, MKT_CAP has a positive association with ROE, with beta coefficient of 0.285 at the $1 \%$ significance level $(p<0.01)$. This further analysis indicates that previous findings using ECAI index have the same results with ECI index that originated from Pae and Choi (2011).

Table 7

Further analysis using ECI indexes

\begin{tabular}{|c|c|c|c|c|c|c|}
\hline & \multicolumn{3}{|c|}{ Model 1} & \multicolumn{3}{|c|}{ Model 2} \\
\hline & $\begin{array}{l}\text { Beta }^{\mathrm{a}} \\
\text { Coefficients }\end{array}$ & $t$ & Sig. & $\begin{array}{l}\text { Beta }^{\mathrm{b}} \\
\text { Coefficients }\end{array}$ & $t$ & Sig. \\
\hline (Constant) & & 0.254 & 0.800 & & -2.377 & $0.018 * *$ \\
\hline COMMT_ECI & 0.198 & 2.712 & $0.007^{*}$ & 0.212 & 3.016 & $0.003 *$ \\
\hline FIRM_SZ & -0.265 & -2.376 & $0.018 * *$ & -0.259 & -2.417 & $0.016 * *$ \\
\hline FIN_LVG & -0.162 & -2.457 & $0.015 * *$ & 0.083 & 1.318 & 0.189 \\
\hline MKT_CAP & 0.200 & 1.851 & $0.065 * * *$ & 0.285 & 2.739 & $0.007 *$ \\
\hline Industry & Included & & & Included & & \\
\hline Adjusted R2 & 0.054 & & & 0.128 & & \\
\hline F-value & $2.155^{* *}$ & & & $3.966^{*}$ & & \\
\hline \multicolumn{7}{|c|}{$\begin{array}{l}\text { aROA }=\beta 0+\beta 1 \text { COMMT_ECI }+\beta 2 \text { FIRM_SZ }+\beta 3 \text { FIN_LVG }+\beta 4 \text { MKT_CAP }+ \\
\beta 5 \text { INDUSTRY } 1 \ldots+\beta 11 \text { INDUSTRY11 }\end{array}$} \\
\hline \multicolumn{7}{|c|}{$\begin{array}{l}\mathrm{bROE}=\beta 0+\beta 1 \mathrm{COMMT} E \mathrm{ECI}+\beta 2 \mathrm{FIRM} \_\mathrm{SZ}+\beta 3 \mathrm{FIN} \_L V G+\beta 4 \mathrm{MKT}+\mathrm{CAP}+ \\
\beta 5 \mathrm{INDUSTRY} 1 \ldots+\beta 11 \mathrm{INDUSTRY} 11\end{array}$} \\
\hline
\end{tabular}

Notes: $* * *$ significant at $10 \%$ significance level $(p<0.10), * *$ significant at $5 \%$ significance level $(p<0.05)$, * significant at $1 \%$ significance level $(p<0.01)$

From the findings, there is evidence to accept $\mathrm{H} 1$ involving the positive association between commitment to ethics and financial performance. The findings are in line with previous studies that were set in other countries such as the US (Verschoor, 1998); Spain (Moneva, Rivera-Lirio, \& Munoz-Torres, 2007); and South Korea (Pae \& Choi, 2011). The results indicate that the stakeholder theory is also applicable in the Malaysian business environment because firms that show their commitment towards ethics receive better return from stakeholders. Results of the multiple regression analysis indicate that management commitment towards ethics is associated with financial performance. The results suggest that the disclosures of a firm's commitment towards ethics affect ROA (ROE), thus supporting H1. 
Stakeholders, such as customers and shareholders, put their trust and loyalty towards firms that are ethical, and accordingly this affects the firm's income. There is evidence that firm size and financial leverage determines a firm's financial performance. Meanwhile, market capital, which reflects a firm's market values, also influences financial performance. The correlation between market capital and ROE indicates that return toward shareholders depends on share prices of the company.

Overall, this study finds that firms that show commitment towards ethics tend to receive better performance. Thus, the hypothesis in this study that management commitment towards ethics is positively associated with financial performance is accepted.

\section{CONCLUSION}

This study investigates the relationship between commitment towards ethics and financial performance among publicly listed companies in Malaysia. In today's highly competitive market coupled with awareness from public about ethical concerns, it is important for companies to commit in fulfilling stakeholders' needs and demands, including committing to serve the community and environment in ethically manners. Findings of this study show that firms that are committed to ethical conduct tend to achieve better performance. The findings, on the benefit of corporate ethical conduct, are in support of stakeholder theory. Also, similar from studies using data from firms in developed countries such as the US, UK, and South Korea, our findings highlight the importance of corporate ethical conduct in a developing country like Malaysia. More specifically, the findings indicate that commitment towards ethical conduct in business operations are needed in order to maintain corporate financial sustainability.

The findings imply the importance of promoting a higher standard of business ethics among publicly listed companies, including in Malaysia. The findings should be taken into consideration by the regulators, in policy formulation involving corporate governance, and by companies in strategy formulation involving business operations. From the perspective of the regulators, this study highlights that good ethical conduct should become a practice of publicly listed companies. Legislative frameworks, which often arise after cases of corporate misconduct, are often treated as just "another hurdle for people who are committed to gaming the system to jump over" (McClean, 2015). Hence, aside from a legislative framework, regulators may incorporate the perspective of the prevention of unethical conduct through emphasising corporate commitments towards ethical conduct in their 
policy making. From the perspective of the Malaysian corporations, this study highlights that good ethical conduct should be emphasised as a culture in organisations. Our study shows that being committed to ethical conduct leads to corporate financial sustainability. By understanding the positive impact of being committed to ethical conduct, companies will be more encouraged to be involved in such practice. This research benefits society as the findings can be incorporated into the formulation and the development of guidelines on ethical corporate conduct that can be further extended to small and medium enterprises, public sectors, and non-profit organisations. This approach can be used to supplement the effort by the government of Malaysia in its quest to combat corruption and unethical misconduct in the country.

Nevertheless, the findings of this study have to be interpreted by considering its limitations. First, the data is only collected for one year period, which is 2014. As there is a possibility that the quality of reporting may improve year by year, future research can extend the dataset to analyse the changes in the quality of reporting involving corporate commitment towards ethical conduct. The recommendation for this limitation towards future research is the researcher can observe in more than two years period. Additionally, future studies can use panel data analysis to see the impact of commitment to ethics towards firms' financial performance. With this method, the quality of reporting can be observed and the changes of reporting can determine whether the firm improves their disclosure about commitment or not, and answering the question did the improvement of reporting have significance relations with financial performance. Furthermore, other types of financial indicators can be used such as market values because its represents current and future firms values (Choi \& Jung, 2008).

Finally, the other limitation is from the scoring method that was used in measuring commitment to ethics by using binary scoring. Binary scoring was used to determine whether the item is disclosed or not. The quality of reporting cannot be determined precisely because the firms only disclosed the item in common statement or standard language, which can be considered as disclosed. Quality of reporting also can be used as an indicator to determine the relationship between firms' commitment to ethics and financial performance. Rating scoring methods can be recommended towards future research to get a more precise result such as that found in Holder-Webb, Cohen, Nath, and Wood (2008). 


\section{ACKNOWLEDGEMENT}

The study is supported by the Fundamental Research Grant Scheme (vote no.: 59468) provided by the Ministry of Higher Education of Malaysia. The authors would like to thank the Ministry for its support.

\section{APPENDIX}

\section{Example of Ethical Commitment Disclosure}

\begin{tabular}{ll}
\hline 1. Top managers of this company regularly emphasise the importance of business ethics \\
\hline $\begin{array}{l}\text { British American } \\
\text { Tobacco (Malaysia) } \\
\text { Berhad }\end{array}$ & $\begin{array}{l}\text { The obligation to comply with the Standards also extends to the } \\
\text { Group's contractors, service providers, suppliers and distributors and } \\
\text { is essential in ensuring high standards of business ethics are similarly } \\
\text { binding on the Group's suppliers and service providers (where } \\
\text { applicable) in ensuring high standards of business ethics amongst all } \\
\text { suppliers and service providers of the Group, including the suppliers' } \\
\text { or service providers' related companies. }\end{array}$ \\
$\begin{array}{l}\text { The directors, officers and employees of the financial institution, } \\
\text { thus, must be seen to conduct their business with the highest level of } \\
\text { morhad }\end{array}$ & $\begin{array}{l}\text { time-tested and generally accepted code of ethics to attain a level of } \\
\text { conduct expected of them, the diversity and complexity of today's } \\
\text { banking world requires that these ethical rules be codified and issued }\end{array}$ \\
as written guidelines in order to promote and maintain a uniform \\
ethical standard.
\end{tabular}




\begin{tabular}{ll}
\hline 2. Ethical behaviour based on a formal business philosophy is the norm of this company. \\
\hline $\begin{array}{l}\text { British American } \\
\text { Tobacco (Malaysia) }\end{array}$ & $\begin{array}{l}\text { Our commitment to sustainability underpins our strategy and our } \\
\text { business. Creating shared value is a priority for us and we do this } \\
\text { by upholding the highest standards of integrity and accountability } \\
\text { throughout our operations. }\end{array}$ \\
$\begin{array}{l}\text { CIMB Group Holdings } \\
\text { Berhad }\end{array}$ & $\begin{array}{l}\text { We are committed to customer satisfaction, truthful advertising, } \\
\text { complying with applicable laws and regulations as well as a high } \\
\text { standard of ethical behaviour and service. }\end{array}$ \\
$\begin{array}{l}\text { Genting Malaysia } \\
\text { Berhad }\end{array}$ & $\begin{array}{l}\text { The Group also upholds integrity as one of its core values and is } \\
\text { committed to acting professionally, fairly and with integrity in all its } \\
\text { business dealings and relationships. }\end{array}$ \\
$\begin{array}{l}\text { Telekom Malaysia } \\
\text { Berhad }\end{array}$ & N/A \\
$\begin{array}{l}\text { Acme Holdings } \\
\text { Berhad }\end{array}$ & N/A \\
$\begin{array}{l}\text { Acoustech Berhad } \\
\text { Ahmad Zaki }\end{array}$ & N/A \\
Resources Berhad & N/A \\
$\begin{array}{l}\text { Al-Aqar Healthcare } \\
\text { REIT }\end{array}$ & N/A \\
Asdion Berhad & N/A
\end{tabular}

3. This company has a disciplinary system through which unethical behaviour is strictly punished.

\begin{tabular}{ll}
\hline $\begin{array}{l}\text { British American } \\
\text { Tobacco (Malaysia) } \\
\text { Berhad }\end{array}$ & $\begin{array}{l}\text { Employees who have been identified as not complying with the safety } \\
\text { guidelines can face disciplinary action. }\end{array}$ \\
$\begin{array}{l}\text { CIMB Group Holdings } \\
\text { Berhad }\end{array}$ & $\begin{array}{l}\text { Disciplinary actions taken can include dismissal of employment and } \\
\text { filing of civil suit for the recovery of losses. Failure to do so may } \\
\text { result in disciplinary action. }\end{array}$ \\
$\begin{array}{l}\text { Genting Malaysia } \\
\text { Berhad }\end{array}$ & N/A \\
$\begin{array}{l}\text { Telekom Malaysia } \\
\text { Berhad }\end{array}$ & $\begin{array}{l}\text { At the same time, we continue to take action against unethical } \\
\text { practices while encouraging the use of the TM Ethics Line. }\end{array}$ \\
$\begin{array}{l}\text { Acme Holdings } \\
\text { Berhad }\end{array}$ & N/A \\
$\begin{array}{l}\text { Acoustech Berhad } \\
\text { Ahmad Zaki }\end{array}$ & N/A \\
Resources Berhad & N/A \\
Al-'Aqar Healthcare & N/A \\
REIT & N/A \\
Asdion Berhad &
\end{tabular}




\begin{tabular}{|c|c|}
\hline $\begin{array}{l}\text { British American } \\
\text { Tobacco (Malaysia) } \\
\text { Berhad }\end{array}$ & $\begin{array}{l}\text { The Standards of Business Conduct describe high standards of } \\
\text { business integrity and code of ethics that guide an employee's } \\
\text { conduct. BATM code. }\end{array}$ \\
\hline $\begin{array}{l}\text { CIMB Group Holdings } \\
\text { Berhad }\end{array}$ & $\begin{array}{l}\text { CIMB Group and its employees adhere to Bank Negara Malaysia's } \\
\text { Code of Ethics BNM/GP7, which promotes proper standards of } \\
\text { conduct and sound and prudent business practices among financial } \\
\text { institutions. } \\
\text { CIMB employees adopt Bank Negara Malaysia's Code of Ethics for } \\
\text { banking institutions. This code outlines the minimum level of conduct } \\
\text { expected from employees. }\end{array}$ \\
\hline $\begin{array}{l}\text { Genting Malaysia } \\
\text { Berhad }\end{array}$ & $\begin{array}{l}\text { The Company recognises that any genuine commitment to detecting } \\
\text { and preventing actual or suspected unethical, unlawful, illegal, } \\
\text { wrongful or other improper conduct must include a mechanism } \\
\text { whereby employees can report their concerns freely without fear of } \\
\text { reprisal or intimidation. }\end{array}$ \\
\hline $\begin{array}{l}\text { Telekom Malaysia } \\
\text { Berhad }\end{array}$ & $\begin{array}{l}\text { TM's Code of Business Ethics supports the Company's vision and } \\
\text { core values by instilling, internalising and upholding the value of } \\
\text { Uncompromising Integrity in the behaviour and conduct of the Board } \\
\text { of Directors, the Management, employees and all stakeholders of the } \\
\text { Company. }\end{array}$ \\
\hline $\begin{array}{l}\text { Acme Holdings } \\
\text { Berhad }\end{array}$ & $\begin{array}{l}\text { The Company's Codes of Ethics for Directors continue to govern the } \\
\text { standards of ethics and good conduct expected of Directors. The Code } \\
\text { of Ethics for Directors includes principles relating to their duties, } \\
\text { conflict of interest and dealings in securities are available at the } \\
\text { Company's website }\end{array}$ \\
\hline Acoustech Berhad & $\begin{array}{l}\text { The Group had established a set of corporate values, ethical } \\
\text { behaviour, and a guidance for quality products and services and these } \\
\text { are set out in the Group's Employee Handbook and safety Handbook. }\end{array}$ \\
\hline $\begin{array}{l}\text { Ahmad Zaki } \\
\text { Resources Berhad }\end{array}$ & $\begin{array}{l}\text { The Standing Instruction on Business Ethics ("the Code") is } \\
\text { communicated to all employees and compliance to the Code is } \\
\text { mandatory. The Code provides guidance and serves as the main } \\
\text { source of reference to assist employees to live up to ethical business } \\
\text { standards and explains how business and duties should be conducted. }\end{array}$ \\
\hline $\begin{array}{l}\text { Al-'Aqar Healthcare } \\
\text { REIT }\end{array}$ & N/A \\
\hline Asdion Berhad & N/A \\
\hline
\end{tabular}




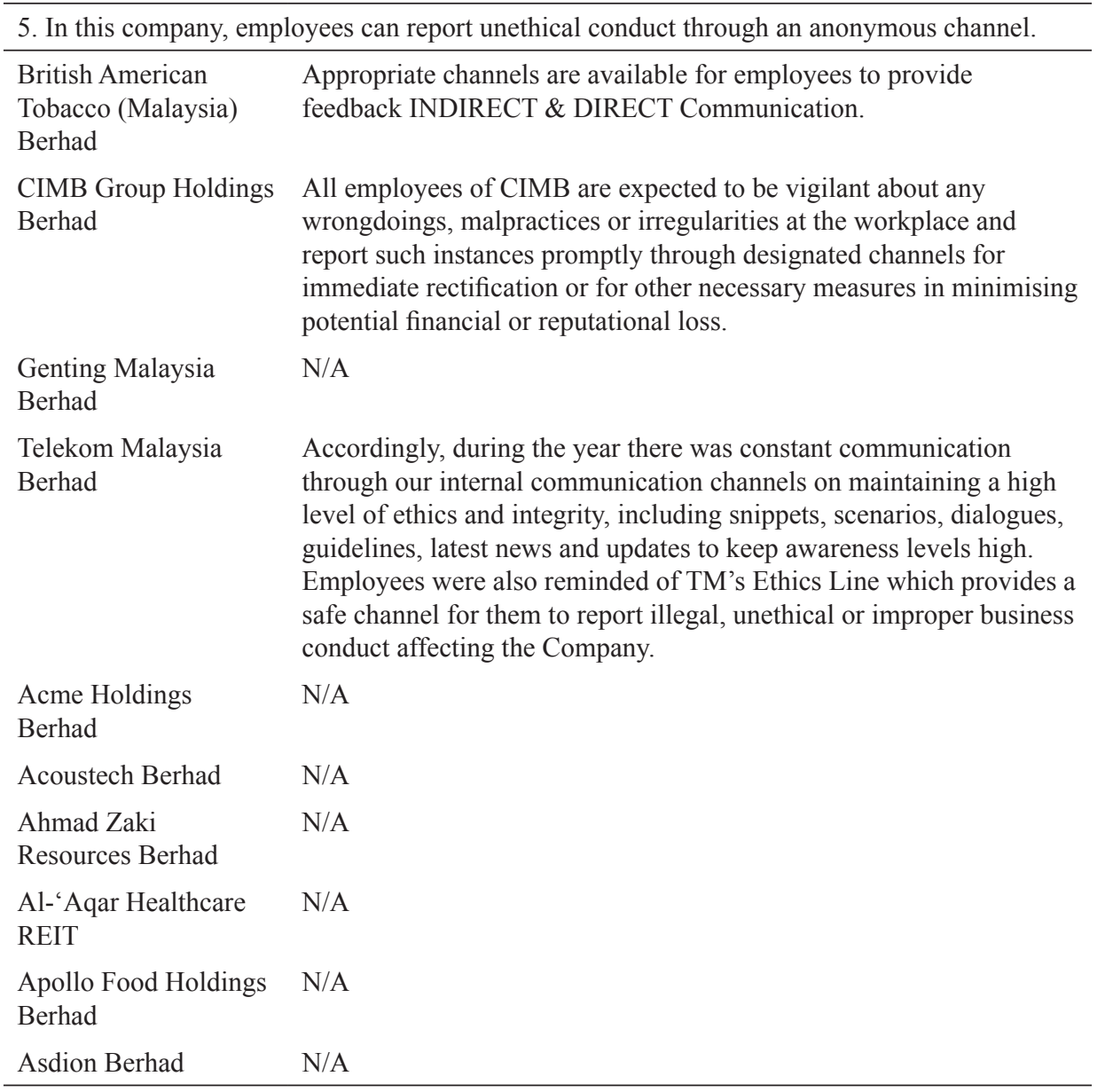

6. In this company, ethics education, training, or workshops are in place to enhance business ethics of employees.

\begin{tabular}{ll}
\hline $\begin{array}{l}\text { British American } \\
\text { Tobacco (Malaysia) } \\
\text { Berhad }\end{array}$ & $\begin{array}{l}\text { Conducted international, regional, and local training for our } \\
\text { employees. }\end{array}$ \\
$\begin{array}{l}\text { CIMB Group Holdings } \\
\text { Berhad }\end{array}$ & $\begin{array}{l}\text { The code is emphasised at the Group Orientation programme and } \\
\text { training programmes when certain aspects are highlighted. }\end{array}$ \\
$\begin{array}{l}\text { Genting Malaysia } \\
\text { Berhad }\end{array}$ & N/A \\
$\begin{array}{l}\text { Telekom Malaysia } \\
\text { Berhad }\end{array}$ & $\begin{array}{l}\text { Company's core value of Uncompromising Integrity and strong } \\
\text { work ethics among the Board of Directors, Management, employees } \\
\text { and all stakeholders of the Company, while at the same time } \\
\text { enhancing our existing multiple integrity initiatives. We also } \\
\text { organised our first ever TM Integrity Day, targeted at employees as } \\
\text { well as business partners. }\end{array}$ \\
\hline
\end{tabular}




\begin{tabular}{ll}
\hline $\begin{array}{l}\text { Acme Holdings Berhad } \\
\text { Acoustech Berhad }\end{array}$ & $\begin{array}{l}\text { N/A } \\
\text { Formal recruitment, training and development, and performance } \\
\text { appraisals are in place to ensure and maintain the professionalism } \\
\text { and competency of staff. }\end{array}$ \\
$\begin{array}{l}\text { Ahmad Zaki Resources } \\
\text { Berhad }\end{array}$ & $\begin{array}{l}\text { In order to nurture the quality and competencies of employees, } \\
\text { training and development programmes are established. }\end{array}$ \\
$\begin{array}{l}\text { Al-Aqar Healthcare } \\
\text { REIT }\end{array}$ & N/A \\
Asdion Berhad & $\begin{array}{l}\text { The Group believe training and development is very important in } \\
\text { developing and upgrading skills, knowledge and attitudes to ensure } \\
\text { optimal performance. Thus, we constantly provide in-house training } \\
\text { programmes to enhance and increase employees job-related skills } \\
\text { knowledge and experience. The Group also committed to career } \\
\text { development of our management and support staff, by sponsoring } \\
\text { key personnel for training and seminars. }\end{array}$ \\
\hline
\end{tabular}

\begin{tabular}{|c|c|}
\hline \multicolumn{2}{|c|}{ 7. This company regularly puts a significant portion of its profits towards philanthropy. } \\
\hline $\begin{array}{l}\text { British American } \\
\text { Tobacco (Malaysia) } \\
\text { Berhad }\end{array}$ & N/A \\
\hline $\begin{array}{l}\text { CIMB Group Holdings } \\
\text { Berhad }\end{array}$ & Contribution for charitable expenses (RM10,151,584). \\
\hline Genting Malaysia Berhad & $\begin{array}{l}\text { GENM Education Fund Committee approved RM } 880,000 \text { in } \\
\text { scholarships for candidates pursuing their studies overseas and } \\
\text { locally. }\end{array}$ \\
\hline $\begin{array}{l}\text { Telekom Malaysia } \\
\text { Berhad }\end{array}$ & $\begin{array}{l}\text { TM had successfully implemented our inaugural Project Giveaway } \\
\text { through which festive hampers and gifts delivered to the Board of } \\
\text { Directors or employees during Hari Raya Aidilfitri were donated. }\end{array}$ \\
\hline Acme Holdings Berhad & N/A \\
\hline Acoustech Berhad & N/A \\
\hline $\begin{array}{l}\text { Ahmad Zaki Resources } \\
\text { Berhad }\end{array}$ & $\mathrm{N} / \mathrm{A}$ \\
\hline $\begin{array}{l}\text { Al-'Aqar Healthcare } \\
\text { REIT }\end{array}$ & $\mathrm{N} / \mathrm{A}$ \\
\hline Asdion Berhad & $\mathrm{N} / \mathrm{A}$ \\
\hline
\end{tabular}

8. This company has an independent ethics department and officers.

\begin{tabular}{ll}
$\begin{array}{l}\text { British American } \\
\text { Tobacco (Malaysia) } \\
\text { Berhad }\end{array}$ & Ethics Valuation Line (EVL). \\
$\begin{array}{l}\text { CIMB Group Holdings } \\
\text { Berhad }\end{array}$ & N/A \\
\hline
\end{tabular}




\begin{tabular}{ll}
\hline Genting Malaysia Berhad & N/A \\
$\begin{array}{l}\text { Telekom Malaysia } \\
\text { Berhad }\end{array}$ & EEIU \\
Acme Holdings Berhad & N/A \\
Acoustech Berhad & N/A \\
$\begin{array}{l}\text { Ahmad Zaki Resources } \\
\text { Berhad }\end{array}$ & N/A \\
Al-'Aqar Healthcare & N/A \\
REIT & N/A \\
Asdion Berhad & \\
\hline
\end{tabular}

9. In this company, employees can get help regarding business ethics through an ethics hotline or open communication channel.

\begin{tabular}{ll}
$\begin{array}{l}\text { British American Tobacco } \\
\text { (Malaysia) Berhad }\end{array}$ & $\begin{array}{l}\text { The revised Standards were duly communicated to all employees } \\
\text { of the Group through an announcement on the Group's intranet } \\
\text { and email notification. The revised Standards have also been } \\
\text { uploaded to the Group's intranet and website respectively. }\end{array}$ \\
$\begin{array}{l}\text { CIMB Group Holdings } \\
\text { Berhad }\end{array}$ & $\begin{array}{l}\text { All employees of CIMB are expected to be vigilant about any } \\
\text { wrongdoings, malpractices or irregularities at the workplace } \\
\text { and report such instances promptly through designated channels } \\
\text { for immediate rectification or for other necessary measures in } \\
\text { minimising potential financial or reputational loss. }\end{array}$ \\
$\begin{array}{ll}\text { Genting Malaysia Berhad } \\
\text { Nelekom Malaysia Berhad }\end{array}$ & $\begin{array}{l}\text { Employees were also reminded of TM's Ethics Line which } \\
\text { provides a safe channel for them to report illegal, unethical or } \\
\text { improper business conduct affecting the Company. }\end{array}$ \\
Acme Holdings Berhad & $\begin{array}{l}\text { N/A } \\
\text { N/A }\end{array}$ \\
Acoustech Berhad & N/A \\
Ahmad Zaki Resources & Nerhad \\
Al-'Aqar Healthcare REIT & N/A \\
\hline Asdion Berhad &
\end{tabular}

\begin{tabular}{|c|c|}
\hline 10. This company has an e & ics committee. \\
\hline $\begin{array}{l}\text { British American Tobacco } \\
\text { (Malaysia) Berhad }\end{array}$ & CSR committee. \\
\hline $\begin{array}{l}\text { CIMB Group Holdings } \\
\text { Berhad }\end{array}$ & Group risk management; Audit Committee. \\
\hline Genting Malaysia Berhad & $\mathrm{N} / \mathrm{A}$ \\
\hline
\end{tabular}




\begin{tabular}{ll}
\hline Telekom Malaysia Berhad & $\begin{array}{l}\text { The establishment of our Enterprise Ethics and Integrity Unit } \\
\text { (EEIU) back in February 2013 is testament of TM's firm } \\
\text { commitment to enhancing and strengthening our corporate } \\
\text { governance and business ethics. }\end{array}$ \\
Acme Holdings Berhad & N/A \\
Acoustech Berhad & N/A \\
Ahmad Zaki Resources & N/A \\
Berhad & N/A \\
Al-'Aqar Healthcare REIT & N/A \\
Asdion Berhad & \\
\hline
\end{tabular}

11. This company has an ethics evaluation system measured by an independent party from outside the company.

\begin{tabular}{ll}
\hline $\begin{array}{l}\text { British American Tobacco } \\
\text { (Malaysia) Berhad }\end{array}$ & $\begin{array}{l}\text { Collaboration amongst Bursa Malaysia Securities Berhad, } \\
\text { Companies Commission of Malaysia, Malaysian Institute of } \\
\text { Integrity, Malaysian Anti-Corruption Commission \& NKRA } \\
\text { Corruption Monitoring \& Coordination Division, Securities } \\
\text { Commission Malaysia. }\end{array}$ \\
$\begin{array}{l}\text { CIMB Group Holdings } \\
\text { Berhad }\end{array}$ & N/A \\
Genting Malaysia Berhad & N/A \\
Telekom Malaysia Berhad & N/A \\
Acme Holdings Berhad & N/A \\
Acoustech Berhad & N/A \\
Ahmad Zaki Resources & N/A \\
Berhad & N/A \\
Al-'Aqar Healthcare REIT & N/A \\
Asdion Berhad &
\end{tabular}

12. The board of this company have establishing the Whistleblowing Policies.

\begin{tabular}{ll}
\hline $\begin{array}{l}\text { British American } \\
\text { Tobacco (Malaysia) } \\
\text { Berhad }\end{array}$ & $\begin{array}{l}\text { The Company has adopted a whistleblowing policy which serves } \\
\text { as an early warning system to assist the Company in detecting } \\
\text { wrongdoings and taking early corrective action. }\end{array}$ \\
$\begin{array}{l}\text { CIMB Group Holdings } \\
\text { Berhad }\end{array}$ & $\begin{array}{l}\text { The whistle-blowing policy provides employees of CIMB with } \\
\text { accessible avenue to report on suspected fraud, corruption, } \\
\text { dishonest practices or other similar matters. }\end{array}$ \\
$\begin{array}{l}\text { Genting Malaysia } \\
\text { Berhad }\end{array}$ & $\begin{array}{l}\text { To this end, the Company has adopted a Whistleblower Policy } \\
\text { which is disseminated to employees. }\end{array}$ \\
$\begin{array}{l}\text { Telekom Malaysia } \\
\text { Berhad }\end{array}$ & $\begin{array}{l}\text { In addition, TM's CBE includes a Whistleblower Policy under } \\
\text { which TM Group employees are encouraged to report concerns } \\
\text { about alleged unethical behaviour, actual or suspected fraud within } \\
\text { the Group. }\end{array}$ \\
\hline
\end{tabular}




\begin{tabular}{ll}
\hline Acme Holdings Berhad & N/A \\
Acoustech Berhad & N/A \\
Ahmad Zaki Resources & N/A \\
Berhad & \\
$\begin{array}{l}\text { Al-'Aqar Healthcare } \\
\text { REIT }\end{array}$ & N/A \\
Asdion Berhad & N/A \\
\hline
\end{tabular}

13. The board of this company committed to achieve business sustainability.

British American

Tobacco (Malaysia)

Berhad

CIMB Group Holdings

Berhad

Genting Malaysia

Berhad

Malayan Banking

Berhad

Telekom Malaysia

Berhad

Acme Holdings Berhad

Acoustech Berhad

Ahmad Zaki Resources

Berhad

Al-'Aqar Healthcare

REIT

Asdion Berhad
British American Tobacco Malaysia's commitment to sustainability underpins our strategy and lies at the heart of our business operations.

As a good corporate citizen, CIMB has shifted its focus from giving back to the community to addressing the concerns of stakeholders regarding issues impacting the long-term sustainability of CIMB's business and customers.

The Group is committed to operating in a sustainable manner and seeks to contribute positively to the well-being of stakeholders.

Sustainability at Maybank means conducting business in a way that enhances performance responsibly - today and over the long-term. We continue to serve ASEAN communities while strengthening and expanding our operations regionally. Our sustainability journey is a reflection of Maybank's position as a regional leader in the provision of financial services and one that supports business growth through impact based approaches.

TM continues to focus on organic growth by building business models that create enduring consumer and employee values. The economic, social and environmental aspects of its operations continue to be managed to ensure long-term viability of the Company's business.

N/A

Across all Group's activities, Acoustech Berhad ("ACOSTEC") Group recognises the responsibility we have towards our people and the communities and environments in which we operate.

ACOSTEC Group continuously develops, implements, maintains, reviews and improves its sustainable development.

N/A

N/A

N/A 
14. The board of this company committed to conduct business in accordance with the highest ethical standards.

British American The Company and its Board of Directors (Board) remain steadfast in its Tobacco

(Malaysia) Berhad commitment in maintaining high standards of corporate governance. The Board firmly believes that the integrity and commitment of its Board and employees, supported by a comprehensive framework of policies, guidelines and internal controls, will serve to strengthen the Company's sustainability, organisational effectiveness and drive a high-performance culture within the organisation.

CIMB Group Holdings Berhad

Genting Malaysia Berhad

Telekom Malaysia Berhad

Acme Holdings

Berhad

Acoustech Berhad

Ahmad Zaki Resources Berhad

Al-'Aqar

Healthcare REIT

Asdion Berhad
CIMB Group Holdings Berhad (CIMB) is fully committed to continuously implementing a sound Corporate Governance Framework to support th Group's pursuit of achieving long-term and sustainable value. It is important that this framework is supported by the right culture, values and behaviours at the top and throughout the entire organisation.

It is the policy of the Company to manage the affairs of the Group in accordance with the appropriate standards for good corporate governance.

At TM, corporate governance remains ingrained in every aspect of the organisation. Coupled with corporate values that uphold strong ethics and Uncompromising Integrity as the foundation for its people, the practice of good corporate governance continues to be strengthened in line with national as well as the organisation's own aspirations.

N/A

N/A

N/A

The Board of Directors of the Manager ("the Board") recognizes the value of good corporate governance and prioritizes in ensuring that high standards of corporate governance is upheld and practised with the ultimate objective of protecting and enhancing unitholders' value and protecting the interests of all stakeholders.

The Company is committed to achieve high standards of corporate governance throughout the Group and highest level of integrity and ethical standards in all of its business dealings. The Board will continue to strive for the full compliance with the Malaysian Code of Corporate Governance in the coming financial year. 


\section{REFERENCES}

Adam, M.H. (2014). Evaluating the financial performance of banks using financial ratios: A case study of Erbil Bank for Investment and Finance. European Journal of Accounting Auditing and Finance Research, 2(2), 156-170.

Advanced Synergy Berhad. (2014). 2014 annual report. Retrieved 28 January 2016 from http://disclosure.bursamalaysia.com/FileAccess/apbursaweb/ download?id=170037\&name=EA_DS_ATTACHMENTS

Allianz Malaysia Berhad. (2014). 2014 annual report. Retrieved 28 January 2016 from https://www.allianz.com.my/documents/144671/150416/Allianz+AR14. pdf/9e08e655-8f3d-4b8d-a4e5-bde14281329b and http://disclosure. bursamalaysia.com/File Access/apbursaweb/download?id=169636\&name=EA_ DS_ATTACHMENTS

Amway (M) Holdings Berhad (2014). 2014 annual report. Retrieved 28 January 2016 from https://ecom-media-prd.sea.amway.net/sys-master/images/h65/ h8b/8801213480990/ AMWAYAnnualReport2014.pdf

Asia Bioenergy Technologies Berhad. (2014). 2014 annual report. Retrieved 28 January 2016 from http://ir.chartnexus.com/asiabioenergy/doc/ar/ASIABIOAnnualReport2014.pdf

Asia Media Group Berhad. (2014). 2014 annual report. Retrieved 28 January 2016 from http://disclosure.bursamalaysia.com/FileAccess/apbursaweb/ download?id=170116\&name=EA_DS_ATTACHMENTS.

ASTRO Malaysia Holdings Berhad. (2014). 2014 annual report. Retrieved 28 January, 2016 from http://corporate.astro.com.my/Portals/default/skins/amh2015/ downloads/investor/annual-reports/AMH-AR14-ENG.pdf

Aturmaju Resources Berhad. (2014). 2014 annual report. Retrieved 28 January 2016 from http://disclosure.bursamalaysia.com/FileAccess/apbursaweb/ download?id=169647\&name=EA_DS_ATTACHMENTS

Bank Negara Malaysia. (2014). Financial stability and payment systems report 2014. Kuala Lumpur: Government Printers. Retrieved 2 January 2016 from https://www.bnm. gov.my/files/publication/fsps/en/2014/fs2014_book.pdf

Berman, S.L., Wicks, A.C., Kotha, S., \& Jones, T.M. (1999). Does stakeholder orientation matter? The relationship between stakeholder management models and firm financial performance. The Academy of Management Journal, 42(2), 488-506. https://doi.org/10.2307/256972

Berrone, P., Surroca, J., \& Tribó, J.A. (2005). Corporate ethical identity as determinant of firm performance: A test of the mediating role of stakeholder satisfaction. Journal of Business Ethics, 76(1), 35-53. https://doi.org/10.1007/s10551-006-9276-1

Bhati, V.D. (2012). A study about employee commitment and its impact on sustained productivity in Indian auto-component industry. European Journal of Business and Social Sciences, 1(6), 34-51.

Bhunia, A., Mukhuti, S.S., \& Roy, S.G. (2011). Financial performance analysis: A case study. Current Research Journal of Social Sciences, 3(3), 269-275. 
Boaventura, J.M., Silva, R.S., \& Bandeira-de-Mello, R. (2012). Corporate financial performance and corporate social performance: Methodological development and the theoretical contribution of empirical studies. Revista Contabilidade \& Finanças, 23(60), 232-245. https://doi.org/10.1590/S1519-70772012000300008

Bosse, D.A., Phillips, R.A., \& Harrison, J.S. (2009). Stakeholders, reciprocity and firm performance. Strategic Management Journal, 30(4), 447-456. https://doi. org/10.1002/smj.743

Boustead Heavy Industries Corporations Berhad. (2014). 2014 annual report. Retrieved 7 March 2016 from http://www.insage.com.my/ir/cmn/downloading. aspx $?$ sFileName $=15071000013656 \&$ sReportType $=$ AR

Callaghan, G.W. (2012). Commitment to business ethics in UK organizations. European Business Review, 24(4), 331-350. https://doi.org/10.1108/09555341211242141

Chandler, D. (2015). Why institutions matter: Stakeholder attention to organizational ethics commitments. In M.S. Kraatz (Ed.), Institutions and ideals: Philip Selznick's legacy for organizational studies (Research in the Sociology of Organizations, volume 44) (pp. 199-233). Emerald Group Publishing Limited. Retrieved 13 January 2016 from: http://www.emeraldinsight.com/doi/full/10.1108/S0733$558 \times 20150000044009$

Choi, T.H., \& Jung, J. (2008). Ethical commitment, financial performance, and valuation: An empirical investigation of Korean companies. Journal of Business Ethics, 81, 447-463. https://doi.org/10.1007/s10551-007-9506-1

Chuan Huat Resource Berhad. (2014). 2014 annual report. Retrieved 14 February 2016 from http://disclosure.bursamalaysia.com/FileAccess/apbursaweb/ download?id=169891\&name=EA_DS_ATTACHMENTS

CIMB Group. (2014a). 2014 annual report. Retrieved 31 January 2016 from http:// www.cimb.com/content/dam/cimbgroup/pdf-files/annual-reports/CIMB AR2014_130415.pdf

CIMB Group. (2014b). 2014 CIMB Group sustainability report. Retrieved 31 January 2016 from http://www.cimb.com/content/dam/cimbgroup/pdf-files/annual-reports/ cimb_sustainability_report_2014.pdf

CN Asia Corporation Berhad. (2014). 2014 annual report. Retrieved 14 February 2016 from http://disclosure.bursamalaysia.com/FileAccess/apbursaweb/ download?id=170146\&name=EA_DS_ATTACHMENTS

Cocoaland Holdings Berhad. (2014). 2014 annual report. Retrieved 14 February 2016 from http://www.cocoaland.com/uploads/annual\%20reports/2014\%20Annual\%20 Report.pdf

Country Heights Holdings Berhad. (2014). 2014 annual report. Retrieved 14 February 2016 from http://disclosure.bursamalaysia.com/FileAccess/apbursaweb/ download?id=169779\&name=EA_DS_ATTACHMENTS

Daibochi Plastic and Packaging Industry Berhad. (2014). 2014 annual report. Retrieved 8 March 2016 from http://www.bursamalaysia.com/market/listed-companies/ company-announcements/4723501

Dixit, D.V., \& Bhati, M.M. (2012). A study about employee commitment and its impact on sustained productivity in Indian auto-component industry. European Journal of Business and Social Sciences, 1(6), 34-51. 
Emas Kiara Industries Berhad. (2014). 2014 annual report. Retrieved 8 March 2016 from http://disclosure.bursamalaysia.com/FileAccess/apbursaweb/ download?id=169646\&name=EA_DS_ATTACHMENTS

Euro Holdings Berhad. (2014). 2014 annual report. Retrieved 15 March 2016 from http://disclosure.bursamalaysia.com/FileAccess/apbursaweb/ download?id=170172\&name=EA_DS_ATTACHMENTS

Ferrell, O.C., Fraedrich, J., \& Ferrell, L. (2011). Business ethics: Ethical decision making and cases (8th ed.). Mason, $\mathrm{OH}$ : South-Western CengageLearning. https://doi. org/10.1007/s10551-010-0675-y

Fischer, T.M., \& Sawczyn, A.A. (2013). The relationship between corporate social performance and corporate financial performance and the role of innovation: Evidence from German listed firms. Journal of Management Control, 24(1), 2752. https://doi.org/10.1007/s00187-013-0171-5

Focus Point Holdings Berhad. (2014). 2014 annual report. Retrieved 15 March 2016 from http://disclosure.bursamalaysia.com/FileAccess/apbursaweb/ download?id=169163\&name=EA_DS_ATTACHMENTS

Fu, G., Wang, J., \& Jia, M. (2012). The relationship between corporate social performance and financial performance: Modified models and their application - Evidence from listed companies in China. Journal of Contemporary Management, 17-37. Retrieved 11 November 2015 from https://pdfs. semanticscholar.org/2f51/90e033c847d840bfa8f8a2b3f74d0659f889.pdf? $\mathrm{ga}=2.30947391 .1872297209 .1507783080-335452713.1507783080$

Ghasemi, A., \& Zahediasl, S. (2012). Normality tests for statistical analysis: A guide for non-statisticians. International Journal of Endocrinology and Metabolism, 10(2), 486-489. https://doi.org/10.5812/ijem.3505

Hair Jr., J.F., Black, W.C., Babin, B.J., \& Anderson, R.E. (2014). Multivariate data analysis (7th ed.). Edinburgh Gate, Harlow: Pearson Education Limited.

Haniffa, R., \& Cooke, T. (2000). Culture, corporate governance and disclosure in Malaysian corporations. Paper presented at the Asian AAA World Conference, 28-30 August 2000, Singapore.

Haniffa, R., \& Hudaib, M. (2007). Exploring the ethical identity of Islamic banks via communication in annual reports. Journal of Business Ethics, 76(1), 97-116. https://doi.org/10.1007/s10551-006-9272-5

Harrison, J.S., Bosse, D.A., \& Phillips, R.A. (2010). Managing for stakeholders, stakeholder utility functions, and competitive advantage. Strategic Management Journal, 31(1), 58-74. https://doi.org/10.1002/smj.801

Harrison, J.S., \& Wicks, A.C. (2013). Stakeholder theory, value, and firm performance. Business Ethics Quaterly, 1(23), 97-124. https://doi.org/10.5840/beq20132314

Harrisons Holdings (Malaysia) Berhad. (2014). 2014 annual report. Retrieved 15 March 2016 from http://www.bursamalaysia.com/market/listed-companies/companyannouncements/4757193

Hartman, L.P., DesJardins, J., \& MacDonald, C. (2014). Business ethics: Decision making for personal integrity and social responsibility (3rd ed.). New York: McGrawHill. 
Higgins, J. (2005). The radical statistician, correlation coefficient. Biddle Consulting Group. Retrieved 29 July 2015 from http://www.biddle.com/documents/ bcg comp_chapter2.pdf

Holder-Webb, L., Cohen, J., Nath, L., \& Wood, D. (2008). A survey of governance disclosures among US firms. Journal of Business Ethics, 83(3), 543-563. https:// doi.org/10.1007/s10551-007-9638-3

Hull, I., \& Rothenberg, S. (2008). Firm performance: The interactions of corporate Social performance with innovation and industry differentiation. Strategic Management Journal, 29, 781-789. https://doi.org/10.1002/smj.675

Jauch, L.R., Glueck, W.F., \& Osborn, R.N. (1978). Organizational loyalty, commitment, and productivity. The Academy of Management Journal, 21(1), 84-92. https://doi. org/10.2307/255664

Kabajeh, M.A.M., Al-Nu'aimat, S.M.A., \& Dahmash, F.N. (2012). The relationship between the ROA, ROE and ROI ratios with Jordanian insurance public companies market share prices. International Journal of Humanities and Social Science, 2(11), 115-120.

Karim, K., Suh, S.H., \& Tang, J. (2016). Do ethical firms create value? Social Responsibility Journal, 12(1), 54-68. https://doi.org/10.1108/SRJ-09-2014-0127

Keim, A.J. (2001). Shareholder value, stakeholder management, and social issues: What's the bottom line? Strategic Management Journal, 22(2), 125-139. https://doi. org/10.1002/1097-0266(200101)22:2<125::AID-SMJ150>3.0.CO;2-H

Krejcie, R.V., \& Morgan, D.W. (1970). Determining sample size for research activities. Educational and Psychological Measurement, 30, 607-610. https://doi. org/10.1177/001316447003000308

Krishnan, L. (2011). A legal scrutiny on the auditor's role to whistle-blow. Jurnal UndangUndang dan Masyarakat, 15, 149-162.

Malayan Banking Berhad. (2014). 2014 annual report. Retrieved 31 January 2016 from http://www.maybank.com/MaybankAR14/pdf/Maybank_AR2014.pdf

McClean, D.E. (2015). Corporate soulcraft. In Wall Street, reforming the unreformable: An ethical perspective (p. 81). New York: Taylor \& Francis. Retrieved 5 June 2016 from https://books.google.com.my/books?id=huA5CgAAQBAJ

McGuire, J.B., Sundgren, A., \& Schneeweis, T. (1988). Corporate social responsibility and firm's financial performance. The Academy of Management Journal, 31(4), 854-872. https://doi.org/10.2307/256342

Meigs, W.B. (1978). Intermediate accounting. New York: McGraw Hill. Retrieved 30 July 2015 from http://shodhganga.inflibnet.ac.in/bitstream/10603/705/11/12 chapter3.pdf

Mia, P., \& Al-Mamun, A. (2009). The level of ethical disclosure of the Islamic banks in Malaysia. International Journal of Management and Entrepreneurship, 5(1), $33-51$.

Mill, J.S. (1961). Utilitarianism. In M. Cohen (Ed.), The philosophy of John Stuart Mill (pp. 321-368). New York: Modem Library.

Millington, S.B. (2008). Does it pay to be different? An analysis of the relationship between corporate social and financial performance. Strategic Management Journal, 29(12), 1325-1343. https://doi.org/10.1002/smj.714 
Moneva, J.M., Rivera-Lirio, J.M., \& Munoz-Torres, M.J. (2007). The corporate stakeholder commitment and social and financial performance. Industrial Management \& Data Systems, 107(1), 84-102. https://doi.org/10.1108/02635570710719070

Neely, A.G. (2005). Performance measurement system design: A literature review and research agenda. International Journal of Operations \& Production Management, 25(12), 1128-1263.

Orlitzky, M. (2001). Does firm size confound the relationship between corporate social performance and firm financial performance? Journal of Business Ethics, 33, 167-180. https://doi.org/10.1023/A:1017516826427

Pae, J., \& Choi, T.H. (2011). Corporate governance, commitment to business ethics, and firm valuation: Evidence from the Korean stock market. Journal of Business Ethics, 100(2), 323-348. https://doi.org/10.1007/s10551-010-0682-z

Pallant, J. (2011). Multicollinearity and singularity. In SPSS survival manual: A step by step guide to data analysis using SPSS (4th ed). Crows Nest NSW: Allen \& Unwin.

Phillips, R., Freeman, E., \& Wicks, A. (2014). Stakeholder theory is an excuse for managerial opportunism. In J.D. Laura \& P. Hartman (Eds.), Business ethics: Decision making for personal integrity and social responsibility (p. 86). New York: McGraw-Hill.

Rajasekar, S., Philominathan, P., \& Chinnathambi, V. (2013). Research methodology. Retrieved 25 November 2015 from http://arxiv.org/pdf/physics/0601009.pdf

Rouf, M.A. (2011). The relationship between corporate governance and value of the firm in developing countries: Evidence from Bangladesh. The International Journal of Applied Economics and Finance, 5(3), 237-244. https://doi.org/10.3923/ ijaef.2011.237.244

Saeidi, S.P., Sofian, S., Saeidi, P., Saeidi, S.P., \& Saaeidi, S.A. (2015). How does corporate social responsibility contribute to firm financial performance? The mediating role of competitive advantage, reputation, and customer satisfaction. Journal of Business Research, 68(2), 341-350. https://doi.org/10.1016/j.jbusres.2014.06.024

Salancik, G. (1977). Commitment and the control of organisational behaviour and belief. In B. Staw \& G. Salancik (Eds.), New direction for organisational behaviour (pp. 1-54). Chicago: St. Clair Press.

Salim, M., \& Yadav, R. (2012). Capital structure and firm performance: Evidence from Malaysian listed companies. Procedia - Social and Behavioral Sciences, 65, 156166. https://doi.org/10.1016/j.sbspro.2012.11.105

Schweitzer, M.E., Ordóñez, L., \& Douma, B. (2004). Goal setting as a motivator of unethical behavior. The Academy of Management Journal, 47(3), 422-432. https://doi.org/10.2307/20159591

Securities Commission Malaysia. (2012). Malaysian Code of Corporate Governance 2012. Retrieved 7 October 2015 from https://www.sc.com.my/wp-content/uploads/eng/ $\mathrm{html} / \mathrm{cg} / \mathrm{cg} 2012 . p d f$

Telekom Malaysia Berhad. (2014). 2014 annual report. Retrieved 31 January 2016 from https://www.tm.com.my/annualreport/2016/images/pdf/past-year-annual-report/ TM_AR2014.pdf 
Valentine, S., \& Barnett, T. (2003). Ethics code awareness, perceived ethical values, and organizational commitment. The Journal of Personal Selling and Sales Management, 23(4), 359-367.

Van der Merwe, R., Pitt, L., \& Berthon, P. (2003). Are excellent companies ethical? Evidence from an industrial setting. Corporate Reputation Review, 5(4), 343358. https://doi.org/10.1057/palgrave.crr.1540183

Verschoor, C.C. (1998). A study of the link between a corporation's financial performance and its commitment to ethics. Journal of Business Ethics, 17(13), 1509-1516. https://doi.org/10.1023/A:1006020402881

Vogel, D. (1991). Business ethics past and present. Public Interest, 102, 49-64.

Waddock, S., \& Graves, S. (1997). The corporate social performance: Financial performance link. Strategic Management Journal, 18(4), 303-319. https://doi.org/10.1002/ (SICI)1097-0266(199704)18:4<303::AID-SMJ869>3.0.CO;2-G

Wang, H., Choi, J., \& Li, J. (2008). Too little or too much? Untangling the relationship between corporate philanthropy and firm financial performance. Organization Science, 19(1), 143-159. https://doi.org/10.1287/orsc.1070.0271

Wang, Y., \& Berens, G. (2015). The impact of four types of corporate social performance on reputation and financial performance. Journal of Business Ethics, 131(2), 337359. https://doi.org/10.1007/s10551-014-2280-y

Watson, T. (2010). Leader ethics and organizational commitment. Mid-Atlantic Leadership Scholars Forum, 3(1), 16-26.

Wells, J.W. (2013). Commitment, ethics and compliance: A look at perceptions in the SH\&E profession. ProfessionalSafety. Retrieved 24 October 2015 from http:// www.murraystate.edu/Libraries/CHSHS_OSH_Documents/Wells_Publication. pdf

Yu, Y., \& Choi, Y. (2014). Corporate social responsibility and firm performance through the mediating effect of organizational trust in Chinese firms. Chinese Management Studies, 8(4), 577-592. https://doi.org/10.1108/CMS-10-2013-0196

Zabri, S.M., Ahmad, K., \& Wah, K.K. (2016). Corporate governance practices and firm performance: Evidence from top 100 public listed companies in Malaysia. Procedia Economics and Finance, 35, 287-296. https://doi.org/10.1016/S22125671(16)00036-8

Zohdi, A., Maghool, A., Ramezani, Y., \& Hosseini, S.E. (2013). The effect of professional commitment on organizational commitments dimensions of Qavamin bank employees in Khorasan Razavi province. International Journal of Advanced Studies in Humanities and Social Science, 1(7), 805-815. 